\title{
Rikollisuus ja sosiaalisen disorganisaation teoria Chicagon sosiologisen koulukunnan tutkimuksissa 1918-1948
}

\author{
VILMA NISKANEN \& PETTERI PIETIKÄINEN
}

Artikkeli tarkastelee sosiaalisen disorganisaation käsitteen ja teorian alkuperää ja kehitystä aatehistoriallisesta näkökulmasta. Lähdeaineistona ovat keskeiset Chicagon sosiologisen koulukunnan julkaisut vuosien 1918 ja 1948 välillä. Kirjoittajien erityishuomio on kohdistunut ensinnäkin sosiaalisen disorganisaation käsitteen esille tuloon ja varhaiseen soveltamiseen William I. Thomasin, Robert E. Parkin ja muiden Chicagon sosiologien kirjoituksissa, ja toiseksi käsitteen ja teorian hyödyntämiseen Clifford R. Shaw'n ja Henry D. McKayn merkittävässä kriminologisessa tutkimuksessa Juvenile Delinquency and Urban Areas (1942). Artikkelissa esitetään, että sosiaalisen disorganisaation teorialla oli keskeinen osa Chicagon sosiologien tutkimuksissa, joissa yhteiskunnallista muutosta ja sosiaalista kontrollia käsitteellistettiin nopeasti kasvavan Chicagon kaupunkielämään keskittyvän empiirisen havainnoinnin pohjalta. Teoria oli laajassa käytössä yhdysvaltalaisessa kriminologiassa ja muissa yhteiskuntatieteissä siksi, että sen avulla kyettiin antamaan uskottavia sosiologisia selityksiä (suur)kaupunkien kasvun ja muutoksen tuomista ongelmista. Teoria joutui suurelta osin marginaaliin 1960-luvulla, mutta 1980-luvulla kriminologinen kiinnostus sosiaaliseen disorganisaatioon alkoi jälleen kasvaa, ja nykyisin teoriaa käytetään kriminologian lisäksi aluetutkimuksessa, kaupunkisosiologiassa ja psykiatriassa.

English summary at the end of the article

Avainsanat: sosiaalinen disorganisaatio - Chicagon sosiologinen koulukunta sosiologian ja kriminologian historia - kaupunkisosiologia 


\section{JOHDANTO}

Sosiaalinen disorganisaatio tarkoittaa yksinkertaistetusti sosiaalisten organisaatioiden puutetta tai niiden löyhyyttä - sosiaalinen organisaatio viittaa laajaan sosiaalisten vuorovaikutussuhteiden verkostoon, joka noudattaa omia lainalaisuuksiaan. Sosiaalisella disorganisaatiolla tarkoitetaan erityisesti tilaa, jossa ihmisten välinen perinteinen vuorovaikutus murtuu tai häviää. Tällöin tapakulttuuri muuttuu ja vakautta ylläpitävät instituutiot, kuten perhe, kirkko ja koulu, menettävät normatiivista merkitystään, minkä seurauksena sosiaalisen elämän ennustettavuus vaikeutuu. Sosiaalinen disorganisaatio kuvaa myös kaupungin, erityisesti suurkaupungin, asukkaiden liikkuvaa, muuttuvaa ja anonyymiutta korostavaa elämäntapaa (Laine, 2007, s. 67).

Sosiaalisen disorganisaation termi on vakiintunut suomalaisessa kriminologiassa, vaikka sen voisi kääntää myös muotoon "sosiaalinen epäjärjestys" tai "hajaannus". Teoriaa ja sen sovelluksia käytetään edelleen varsinkin kriminologiassa, mutta myös muissa yhteiskuntatieteissä sekä lääketieteessä, erityisesti psykiatriassa (Junnilainen, 2019; Kivivuori ym., 2018, s. 201-202, 216-217; Boydell \& Murray, 2003; Silver ym., 2002). Teorian mukaan rikollisuuden alueellinen esiintyvyys, asuinalueiden väestöllinen rakenne ja sosiaaliset suhteet ovat yhteydessä toisiinsa. Kriminologit selittävät teorian avulla sekä rikostapahtumien alueellista vaihtelua että rikoskäyttäytymiselle altistavien alueellisten tekijöiden vaihtelua (Kivivuori ym., 2018, s. 210-211; teoria tunnetaan nykyisin myös yhteispysyvyyden teoriana [collective efficacy theory], ks. Kivivuori ym., 2018, s. 212; Shoemaker, 2010, s. 119-120.).

Sosiaalisen disorganisaation teoriasta ja sen merkittävimmistä tutkijoista on kirjoitettu kansainvälisissä sosiologisissa ja kriminologisissa yleisteoksissa (Salerno, 2007; Downes ym., 2016; Shoemaker, 2010; Cullen \& Wilcox, 2010; Suomessa Kivivuori ym., 2018 ja Laine, 2007). Tarkemmin aihetta kontekstualisoivaa aate- ja tieteenhistoriallista tutkimusta teorian alkuvaiheista ei ole kuitenkaan tehty sen enempää Suomessa kuin kansainvälisestikään, ja tätä puutetta artikkelimme korjaa. Tarkastelemme artikkelissamme sosiaalisen disorganisaation teoriaa ja sen varhaista käyttöä rikollisuuden selittämiseen Chicagon yliopiston sosiologiassa. Vuosien 1918 ja 1925 välillä sosiaalisen disorganisaation käsite muodostui teoriaksi, jonka painopiste siirtyi 1940-luvulla sosiologiasta kriminologiaan. Teorian kehityksen vuosisadan jälkimmäisen puoliskon samoin kuin nykytilanteen analysoinnin rajaamme tämän artikkelin ulkopuolelle. Tarkastelemme keskeisiä sosiaalisen disorganisaation käsitettä ja teoriaa muotoilleiden tutkijoiden julkaisuja. Haemme vastausta kysymyksiin i) miten sosiaalisen disorganisaation teoria syntyi Chicagon sosiologiassa, ii) miten teorialla selitettiin rikollisuuden esiintymistä ja iii) millaisena sosiaalisen disorganisaation prosessi tutkijoiden mukaan ilmeni.

\section{METODI, AINEISTO JA RAKENNE}

Artikkelissamme hyödynnämme kriminologisen tutkimuksen aatehistoriallista menetelmää (Kivivuori ym., 2018). Olemme analysoineet sosiaalisen disorganisaation teorian syntyvaiheeseen ja kehitykseen vaikuttavia tieteen ulkoisia ja sisäisiä tekijöitä. Analyysissamme olemme tulkinneet teoriaa muodostaneiden Chicagon sosiologisen koulukunnan tutkijoiden kirjoituksia. Olemme sijoittaneet lähteissä esitetyt eksplisiittiset havainnot, väitteet ja päätelmät sekä tekstistä epäsuoremmin tulkittavissa olevat oletukset 
ja uskomukset tuolloin Chicagon sosiologiaan vaikuttaneisiin tieteellisiin ja aatteellisiin ajattelutapoihin ja muihin relevantteihin tekijöihin kuten setlementtiliikkeseen.

Aatehistorioitsijaa kiinnostavat ajattelun kontekstit eli asiayhteydet. Aatehistoriassa perehdytään kunkin aikakauden ajattelijoiden aikomuksiin ja uskomuksiin ja myös "aikomusten ja uskomusten edellytyksiin" (Manninen, 2004, s. 68). Kuten aate- ja tieteenhistoriallista tutkimusta edustava Ajatusten lähteillä -teos asian esittää, "osa konteksteista liittyy ajattelijan lähipiiriin, arkielämään ja tämän tietoisesti auki kirjoitettuihin motiiveihin, osa taas yleiseen vallitsevaan kulttuuriin ja laajempiin yhteiskunnallisiin kehityskulkuihin" (Helo \& Pietikäinen, 2017, s. 22). Aatehistoriallinen tutkimus on pätevä ainoastaan omalla tarkasti rajatulla aihealueellaan - tarkoituksena on selvittää tutkimusaiheen merkitys sen omassa ajassa ja paikassa eikä esittää väitteitä aiheen merkityksellisyydestä tai merkityksettömyydestä esimerkiksi tämän päivän maailmalle.

Aatehistoriallinen tulkintamme sosiaalisen disorganisaation teorian alkuvaiheista ja sen varhaisesta kriminologisesta soveltamisesta ei pyri kaikenkattavaan selitykseen teoriasta eikä sen pätevyydestä nykytutkimukselle. Pyrimme sen sijaan käsittämään, miten teorian varhaiset muotoilijat itse sen käsittivät. Koska ajatus sosiaalisesta organisaatiosta ja disorganisaatiosta syntyi ja kehittyi Chicagon sosiologisen koulukunnan piirissä 1910-luvun lopulta alkaen, käytämme lähteinämme Chicagon sosiologien kirjoituksia, joista osa ilmestyi koulukunnan "omassa" lehdessä American Journal of Sociology. (Lehden historiaa tutkineen sosiologi Andrew Abbottin mukaan lehti oli "monin tavoin oppiaineen tekijä" eikä toisin päin [Abbott, 1999, s. 137]). Lähdekirjallisuuden tukena ja kon- tekstin luomiseksi olemme käyttäneet Chicagon sosiologiasta kirjoitettuja teoksia, joista yksikään ei sinänsä keskity sosiaalisen disorganisaation teoriaan (sellaisia tutkimuksia ei ole).

Analyysimme lähtee liikkeelle Chicagon koulukunnan varhaisvaiheista ja samalla sosiaalisen disorganisaation teorian syntyvaiheesta. Lähempänä tarkastelun kohteena on W.I. Thomasin ja Florian Znanieckin laaja teos The Polish Peasant in Europe and America Polish Peasant (1918-1920/1984). Seuraavassa osiossa tarkastelemme teoriaa Chicagon kaupunkisosiologian kontekstissa, jonka jälkeen keskitymme artikkelimme toiseen päälähteeseen, Clifford R. Shaw'n ja Henry D. McKayn teokseen Juvenile Delinquency and Urban Areas (1942/1972). Lopuksi tarkastelemme lyhyesti teorian vaiheita 1940-luvulta 1960-luvulle, johon mennessä teoria samoin kuin koko koulukunta oli joutunut marginaaliin Yhdysvalloissa.

\section{TULOKSET}

\section{Chicagon sosiologinen koulukunta}

Sosiaalisen organisaation teorian "pääkaupunkina" voi pitää Chicagoa. Kaupunki kasvoi ja teollistui nopeasti 1800-luvun puolivälistä lähtien, ja 1900-luvun alussa puolet Chicagon 1,7 miljoonasta asukkaasta oli syntynyt Yhdysvaltain ulkopuolella. Etelävaltioiden mustien siirtolaisuus Chicagoon ja muihin pohjoisen kaupunkeihin käynnistyi toden teolla ensimmäisen maailmansodan aikana ja heti sen jälkeen (tästä ns. Great Migrationista ks. Wilkerson, 2020). Vuonna 1930 mustien osuus Chicagon väestöstä oli 7 prosenttia. (Bulmer, 1984, s. 13). Chicagossa näkyivät kaupungistumiseen liittyvien sosiaalisten muutosten kielteiset lieveilmiöt, kuten rikollisuus, työttömyys ja mielenterveyshäiriöt 
(Johnson \& Sautter, 1994; Downes ym., 2016). Chicagon sosiologit loivat yhdeksi selitysmalliksi sosiaalisille ongelmille ja niiden esiintyvyydelle sosiaalisen disorganisaation teorian.

Chicagon sosiologian laitos oli todennäköisesti ensimmäinen empiiriseen tutkimukseen perustunut sosiaalitieteellinen yksikkö koko maailmassa. Tutkimus keskittyi pääasiassa kaupunkielämän marginaalisiin ilmiöihin ja ryhmiin, nojasi pitkälti kenttätyöhön ja sai innoituksensa tutkijoiden empiirisestä ja ennakkoluulottomasta kiinnostuksesta ympäristöönsä. Teoksissaan he käyttivät osin samoja kirjoitustekniikoita kuin toimittajat ja kirjailijat. Ränsistyvät talot ja levottomat kadut, amerikkalaiseen elämänmenoon totuttelevat siirtolaiset, kurittomat nuorisorikolliset, ammattimaiset rikollisjengit, maksulliset naiset ja juurettomat kulkurit kiehtoivat Chicagon sosiologeja, ja he nostivat nämä urbaanit ilmiöt tutkimuksensa kohteiksi. Sosiologien puhe seksistä, sukupuolisuudesta ja poikkeavuuksista oli samalla ennennäkemättömän avointa. (Salerno, 2007).

Chicagon koulukunta dominoi yhdysvaltalaista sosiologiaa 1900-luvun ensimmäisinä vuosikymmeninä (Bulmer, 1984). Erityisesti vuosien 1915-1935 välillä Chicagossa tehtiin runsaasti tutkimusta, joka resonoi urbaanien yhdysvaltalaisten todellisuuden kanssa. Koulukunnalla on perustajansa, kuten W.I. Thomas ja Robert E. Park, mutta kyse ei ole mistään kodifioidusta tutkimusohjelmasta vaan joukosta varsin löyhiä teoreettisia tai metodologisia lähtökohtia, joiden perustalle koulukunnan tutkimus kehittyi. Vuonna 1939, jolloin Park oli jo siirtynyt afroamerikkalaiseen Fisk-yliopistoon Nashvillessa, hän ei

\footnotetext{
${ }^{1}$ Yliopisto muun muassa hyväksyi opiskelijoiksi tavallista enemmän afroamerikkalaisia.
}

halunnut kuvata Chicagon varhaista sosiologiaa "koulukunnaksi". Chicagon tutkijat eivät hänen mukaansa olleet tietoisia siitä, että he olisivat luomassa koulukuntaa tai useimmissa tapauksissa edes mitään "opinkappaletta" (engl. doctrine). (Park, 1939.)

Chicago oli kaupunkina nuori, levoton ja Bostonin ja New Yorkin kaltaisiin vakiintuneisiin keskuksiin nähden hengeltään demokraattisempi. Myös Chicagon yliopistossa vallitsi Harvardin ja Yalen kaltaisiin perinteisiin yliopistoihin nähden varsin salliva ja avoin ilmapiiri. ${ }^{1}$ Chicagon antielitistinen ilmapiiri vaikutti myös yliopiston sosiologeihin, jotka jo varhain kiinnostuivat tavallisista kaupunkilaisista ja heidän elämästään, johon kuului työttömyyttä, rikollisuutta, kapakoita, tappeluja, uhkapelejä, avioeroja ja muita sosiaalisia ongelmia ja moraalisia paheita. James T. Careyn vertailevan tutkimuksen mukaan Chicagon sosiologit olivat muihin aikakauden amerikkalaistutkijoihin verrattuna selvästi useammin syntyneet isoissa kaupungeissa, ja he olivat sekä etnisesti heterogeenisempiä että vähemmän uskonnollisia. He olivat erityisesti muihin varhaisiin yhdysvaltalaissosiologeihin verrattuna myös poliittisesti liberaalimpia ja heidän joukossaan oli enemmän naispuolisia tutkijoita kuin vertailuryhmissä. (Carey, 1975, s. 44-48).

Sosiologian laitoksen perustajan Albion W. Smallin tavoitteena oli tuottaa yhteiskunnallisessa kehitystyössä hyödynnettävää tietoa, ja tämä reformistinen henki näkyi jossain määrin Chicagon sosiologiassa sen kulta-aikana eli vuosina 1915-1935. Parkin pragmaattinen, antielitistinen tutkimusasenne puolestaan näkyi siinä, että jotkut sosiologian laitoksen väitöskirjantekijöistä olivat itsekin 
köyhiä siirtolaisia (kuten romanialaissyntyinen, Chicagon järjestäytynyttä rikollisuutta tutkinut John Landesco) tai levottoman nuoruuden eläneitä (esimerkiksi klassisen The Hobo -teoksen kirjoittaja Nels Anderson).

Chicagon sosiologit saivat vaikutteita Euroopasta, erityisesti Saksasta. Albion W. Small oli ollut kiinnostunut kaupunkisosiologi Georg Simmelin ajattelusta ja oli kääntänyt tämän tekstejä 1890-luvulta lähtien. Chicagosta myös lähetettiin oppilaita Simmelin oppiin Berliiniin. William I. Thomas oli Chicagon sosiologian tärkein ja valovoimaisin hahmo ennen Parkin tuloa laitokselle, ja Thomasin rooli Parkin houkuttelemisessa Chicagoon oli ratkaiseva. ${ }^{2}$ Saksassa opiskelleeseen Thomasiin oli tehnyt vaikutuksen sikäläinen Völkerpsychologie, jonka edustajat pyrkivät objektiivisesti ja huolellisesti keräämään vertailevaa aineistoa esiteollisen Euroopan talonpoikaisyhteisöistä. Tämä sosiaalipsykologisesti värittynyt etnografinen menetelmä näkyi sekä Thomasin varhaisemmassa tuotannossa että Polish Peasant -teoksessa (Bulmer, 1984, s. 36).

Robert E. Park puolestaan työskenteli alun perin sanomalehtitoimittajana, ennen kuin jatkoi opintojaan Harvardissa William Jamesin johdolla 1890-luvun lopulla. Harvardista hän siirtyi Saksaan, jossa hän viimeisteli väitöskirjansa Heidelbergin yliopistossa; Berliinissä Park osallistui Georg Simmelin luennoille. Lyhyessä omaelämäkerrassaan vuodelta 1927 Park kirjoittaa, ettei hän koskaan saanut mitään systemaattista sosiologian koulutusta Simmelin luentoja lukuun ottamatta. $^{3}$

\footnotetext{
${ }^{2}$ Thomasin ja Parkin lyhyet omaelämäkerrat on julkaistu, ks. Baker, 1973.

${ }^{3}$ Park toteaa, että Simmelin avulla "I finally gained a fundamental point of view for the study
}

Park oli kiinnostunut tavasta, jolla Simmel ja muut saksalaiset kaupunkisosiologit käyttivät aineistonaan sanomalehtiä ja populaarikulttuuria. Esimerkiksi journalisti ja tutkija Hans Ostwaldin vuosina 1904-1908 toimittama, 51:stä niteestä koostuva Großstadt-Dokumente tallensi 1800-1900-lukujen taitteen Berliinin ja Wienin populaarikulttuuria ja katuelämää eri näkökulmista. Tutkimukset oli tehty havainnoimalla kaupunkielämää paikan päällä ja tekemällä vertailuja modernin Berliinin ja perinteisemmän Wienin välillä (Fritzsche, 1994). Großstadt-Dokumente ei vaikuttanut merkittävästi saksalaistutkimukseen, mutta julkaisusarjaan ja itse Berliiniin tutustuneen Parkin myötä sen välittämät ajatukset ja menetelmät tulivat osaksi Chicagon koulukunnan tutkimuksia. Vuonna 1914 Chicagon yliopiston kirjasto osti sarjan kaikki 51 osaa, ja lainauskorttien historiallinen tutkimus on osoittanut, että muun muassa W. I. Thomas perehtyi teossarjaan (Kivivuori ym., 2018, s. 51). Park oli jo sanomalehtitoimittajan työssään ollut kiinnostunut yhteiskunnan marginaaliin jäävien ihmisten ja ilmiöiden tutkimisesta, mukaan lukien siirtolaiset, köyhät, musta väestö ja kaupungin alamaailma (Park otti 1920-luvulla käyttöön termin "Marginal Man"; ks. Park, 1928). Historioitsija Peter Fritzschen mukaan saksalaistutkimukset myös tarkastelivat kaupunkia ekologisena systeeminä, ja Park toi näkemyksen yhdysvaltalaiseen sosiologiaan (Fritzsche, 1994, s. 389, 396-397; ks. myös Jazbinsek ym., 2001, s. 1-9).

Saksasta palattuaan Park toimi useita vuosia afroamerikkalaisen pedagogin ja yhteiskun-

of the newspaper and society" (Baker, 1973, s. 256-257). 
tavaikuttajan Booker T. Washingtonin avustajana. Park ja Thomas tapasivat Washingtonin järjestämässä konferenssissa 1912, ja seuraavana vuonna Park siirtyi Chicagoon; hänen ensimmäisen luentokurssinsa aihe oli "The Negro in America". (Bulmer, 1984, s. 35-36, 62). Vaikka ajatus Chicagosta sosiaalitutkimuksen laboratoriona oli esitetty sosiologian laitoksella jo vuosisadan alussa (Kurtz, 1984, s. 60-61), niin erityisesti Parkin myötä Chicagon sosiologia muodostui kaupunkisosiologiaksi. ${ }^{4}$

Parkille kaupunki oli elävä organismi, jonka rakenne samalla pohjautui "ihmisluontoon" kaupunki oli hänelle ihmisluonnon ilmaisu. Ei siis ihme, että ekologinen lähestymistapa kaupunkiin tuli Parkin ja koko Chicagon koulukunnan ominaispiirteeksi. Parkin yhtenä sosiologisena metodina oli tutustua kävellen ja havaintoja tehden kaupungin eri osiin; tämän tavan hän oli omaksunut toimiessaan sanomalehtireportterina muun muassa New Yorkissa ja Detroitissa vuosien 1887 ja 1898 välillä. Park itse kertoi lukuisten kävelyretkiensä tuoneen hänelle oivalluksen, että kaupunki ei ole vain maantieteellinen ilmiö vaan myös eräänlainen "sosiaalinen organismi". Parkin urbaanisosiologian ohjenuorana oli ajatus, että ihmisiä on tutkittava heidän luonnollisessa ympäristössään (Bulmer, 1984, s. 90-92). Kuten koulukuntaa tutkinut sosiologi Andrew Abbott on todennut, Chicagon sosiologeille empiirisen tutkimuksen tuottamat sosiaaliset faktat oli sijoitettava tiukasti yhteiskunnalliseen todellisuuteen, konkreettiseen

\footnotetext{
${ }^{4}$ Kuten Park kirjoitti American Journal of Sociology -lehdessä kohta Chicagoon muuttonsa jälkeen, "the city is rooted in the habits and customs of the people who inhabit it. The consequence is that the city possesses a moral as well as a physical organization, and these two mutually interact
}

aikaan ja paikkaan, yhteisöihin ja niiden toimijoihin, ihmisiin, mikä samalla tarkoitti näiden faktojen kontekstien huomioimista ja "byrokratian", "kapitalismin", "moderniteetin" ynnä muiden abstraktien käsitteiden välttämistä. (Abbott, 1999, s. xi, 3, 31, 196-197).

Chicagon urbaanisosiologian keskeinen tavoite oli kuvata ja selittää (suur)kaupunkien vaikutusta ihmisen käyttäytymiseen ja persoonallisuuteen, sosiaalisen elämän subjektiiviseen puoleen, ja tästä syystä kaupunkielämän "psykososiaalinen" ulottuvuus oli koulukunnan sosiologien tutkimuskohde. Vaikutteita tähän oli saatu erityisesti William Jamesilta ja John Deweylta. Klassikkoteoksessaan The City (1925/2019), Park ja Burgess kuvasivat Chicagon kaltaisia kaupunkeja "kollektiivisen käyttäytymisen tutkimuslaboratorioksi” (Park \& Burgess, 2019, s. 22).

\section{Setlementtiliike ja Chicagon sosiologia}

Akateemista sosiologiaa edelsi laajamittainen sosiaalityö eri puolilla Yhdysvaltoja. Samalla kun saksalaisen kaupunkisosiologian vaikutteet olivat ilmeiset Chicagon sosiologiassa, oli käytännön sosiaalityön ja erityisesti setlementtiliikkeen vaikutus merkittävä yhdysvaltalaisen sosiaalitieteen muotoutumiselle (Deegan, 1981; Deegan, 1988; Deegan, 2005; Downes ym., 2016; Grant ym., 2002; Williams \& MacLean, 2015, s. 6-9). ${ }^{5}$

Chicagon sosiologisen koulukunnan alkuhistoriaan vaikutti merkittävä setlementti, Hull

in characteristic ways to mold and modify one another." (Park, 1915, s. 578.)

5 Setlementtiliikkeen juuret ovat 1880-luvun Lontoossa, jossa slummien asukkaiden oloja pyrittiin parantamaan sosiaalityön keinoin. Liikkeen taustalla oli ajatus sosiaalisesta yhdenvertaisuudesta ja paikallisesta vaikuttamisesta. 
House, jonka perustivat sosiaalireformisti Jane Addams ja hänen ystävättärensä Helen Gates Starr eteläiseen Chicagoon vuonna 1889 (Addamsista sosiaalityön kehittäjänä ks. Puurunen, 2019). Kolme vuotta ennen Chicagon yliopiston sosiologian laitosta perustettu Hull House veti puoleensa sosiaalisten olojen parantamisesta kiinnostuneita naisia ja miehiä niin akateemisesta maailmasta kuin sen ulkopuolelta. (Deegan, 2005; Springer \& Roberts, 2006, s. xiii-xiv) Setlementistä käsin tehdyn sosiaalireformistisen työn tarkoitus oli auttaa slummialueiden köyhiä, useimmiten siirtolaistaustaisia ihmisiä, sekä tutkia samalla huono-osaisuuteen johtavia sosiaalisia olosuhteita (Addams ym., 1895, prefatory note, s. 207-260). Vaikutteet Hull Housen setlementtiin tulivat suoraan Lontoon tunnetuimmasta setlementistä, Toynbee Hallista, jossa Addams oli vieraillut vuonna 1889 (Williams \& MacLean, 2015, s. 45-46, 80-85).

Jane Addams ja muut, pääasiassa naispuoliset setlementtivaikuttajat kirjoittivat paljon köyhyydestä, siirtolaisuudesta, naisten asemasta, nuorisorikollisuudesta, vanhuudesta ja muuttuvista amerikkalaisista arvoista. Setlementtiliikkeen myötä Chicagossa myös omaksuttiin brittiläisen sosiaalireformistin Charles Boothin kaupunkitutkimukseen kehittämä kartoittamismenetelmä. Booth oli luonut 1800-luvun lopulla Lontoon slummialueista värikoodattuja karttoja, joiden avulla hän tutki köyhyyden, ammattien, yhteisöjen ja sosiaalisen elämän välisiä suhteita. Jane Addams ja hänen työtoverinsa käyttivät Boothin mallia kartoittaessaan Chicagon asukkaiden sosioekonomista asemaa slummialueilla. (Deegan, 1988, s. 303-305.) He esittivät tuloksensa vuonna 1895 teoksessa Hull House Maps and Papers, joka toimi sit- temmin menetelmällisenä esimerkkinä ja innoittajana sosiologisen koulukunnan tutkimuksille.

Hull Housen kollektiivi ja yliopiston sosiologian laitos tekivät vuosisadan vaihteessa runsaasti yhteistyötä (Grant ym., 2002, s. 6970). Jane Addamsin vaikutus yliopistolla oli ilmeinen, sillä hän kirjoitti useita artikkeleita Albion W. Smallin vuonna 1895 perustamaan American Journal of Sociology -lehteen ja luennoi yliopistolla muun muassa tutkimusmenetelmistä (Grant ym., 2002, s. 70, 86-88; Williams \& MacLean, 2015, s. 8788). Hull Housessa puolestaan järjestettiin tieteellisiä konferensseja ja joitakin Chicagon yliopiston sosiologian kursseja. Esimerkiksi W. I. Thomas oli yksi säännöllisistä luennoitsijoista Hull Housessa. (Zaretsky, 1984, s. 9.)

Thomasin kiinnostus siirtolaisuuteen syntyi osin hänen siteistään setlementtitoimintaan. Lisäksi hän sai sitä kautta mittavan viidenkymmenen tuhannen dollarin rahoituksen (nykyarvoltaan noin 1,3 miljoona dollaria) siirtolaistutkimukseensa. Rahan myönsi vuonna 1908 perustettu Helen Culver Fund for Race Psychology -rahasto, jota myös Thomas oli perustamassa ja jonka puheenjohtajana hän toimi. Helen Culver oli varakas perijätär, joka omisti Hull Housen käyttöön vuokratun Hull Mansion -kiinteistön. (Zaretsky, 1984, s. 8-9) Setlementtivaikuttajat olivat julkaisseet siirtolaisuutta koskevaa tutkimusta, mikä toimi innoittajana Polish Peasantin luomisessa. Esimeriksi Emily Green Balch oli vuonna 1910 julkaissut teoksen Our Slavic Fellow Citizen, joka käsitteli siirtolaisia ja sosiaalista muutosta. Samat teemat löytyvät Polish Peasant -teoksesta. (Deegan, 1981, s. 17.) Setlementin parissa tehty työ edelsi merkittävällä tavalla Chicagon sosiologisen koulukunnan tutkimuksia. 
Chicagon sosiologeille setlementit avasivat portteja kaupungin köyhien alueiden elämään. Vuosisadan vaihteesta lähtien yliopiston opiskelijat tekivät tutkielmia slummi- ja tehdasalueista, osin yhteistyössä setlementtien kanssa. Setlementtiliikkeellä ja yliopiston tutkimuksilla oli kuitenkin perustavanlaatuinen ero: yliopistot pyrkivät tuottamaan objektiivista tietoa, setlementit puolestaan toimivia sosiaalityön muotoja. Setlementeille kaupunki ja sen slummialueet eivät olleet "laboratorio", sillä niiden toiminta kohdistui konkreettiseen reformityöhön. Erityisesti Addamsille oli tärkeää säilyttää setlementin itsenäisyys eikä luovuttaa päätäntävaltaa Rockefeller-rahoitteisen yliopiston hallinnolle. (Williams \& MacLean, 2015, s. 89, 135-137.)

1890-1920-luvuilla Chicagossa vallitsi siis kaksi urbaanisosiologista tietoa tuottavaa instituutiota: käytännönläheinen, naisvaltainen setlementtiliike ja miesvaltainen sosiologian laitos yliopistolla. Jälkimmäisen voi katsoa saaneen runsaasti vaikutteita ja apua ensimmäisestä. Tiiviistä yhteistyöstä huolimatta suunnat erosivat 1920-luvulta lähtien. Siinä missä miestutkijoista tuli sosiologeja, heidän naispuolisista kollegoistaan tuli "soveltavan sosiologian" edustajia eli sosiaalityöntekijöitä. (Deegan, 1981, s. 14-17; Deegan, 2005, s. 30-31.) Chicagon sosiologien joukossa oli silti myös naisia, kuten itsemurhasta kirjoittanut Ruth Shonle Cavan ja metodologiaa ja erityisesti kenttätutkimusmenetelmiä kehittänyt Vivian Palmer.

Chicagon koulukuntaan kuului keskeisiä mustien kaupunkilaisten elämää sosiologisesti tarkastelevia afroamerikkalaisia tutkijoita. Ei ole suinkaan sattumaa, että Chicagon

\footnotetext{
${ }^{6}$ Johnson teki tutkimuksensa rotulevottomuuksien jälkeen perustetun Chicago Commission on Race Relations -komitean toimeksiantona.
}

sosiologian laitos tarjosi mahdollisuuksia mustille sosiaalitieteilijöille: Park oli ennen Chicagoon tuloaan työskennellyt mustien oikeuksia ajaneen Booker $\mathrm{T}$. Washingtonin avustajana, toimien muun muassa hänen tekstiensä haamukirjoittajana ja PR-agenttina. Varhaisin Chicagon mustista sosiologeista oli Charles S. Johnson, joka kirjoitti laajan, Parkin urbaanisosiologiasta vaikutteita saaneen teoksen vuoden 1919 väkivaltaisista rotulevottomuuksista Chicagossa (The Negro in Chicago, 1922). ${ }^{6}$ E. Franklin Frazierin The Negro Family in Chicago (1932) ja varsinkin The Negro Family in the United States (1939) ovat puolestaan merkittäviä empiirisiä tutkimuksia mustien perheiden ahdingosta. Frazieria oli työssään inspiroinut Chicagon sosiologien emansipatorinen tiedon intressi ("knowledge would set you free”) (Teele, 2002, s. 3). Vähän myöhemmin tutkivat mustien Chicagoa myös sosiologian laitoksen jatko-opiskelijat Horace R. Cayton ja St. Clair Drake. Heidän yhteisteoksensa Black Metropolis (1945), jonka he omistivat vastikään edesmenneelle "mustien ystävälle" (friend of the Negro people) Parkille, oli uraauurtava urbaanisosiologinen tutkimus mustien asuttamasta South Sidesta Chicagossa. Merkittävä koulukunnalta vaikutteita saanut afroamerikkalainen oli myös Black Metropolisiin johdannon kirjoittanut kirjailija ja intellektuelli Richard Wright, joka tuli vuonna 1940 julkaistulla Native Son -teoksellaan kertaheitolla tunnetuimmaksi mustaksi kirjailijaksi Yhdysvalloissa. 
Puolalaissiirtolaiset Chicagossa: sosiaalisen disorganisaation teorian synty

Rikollisuuden ja erityisesti nuorisorikollisuuden tutkimus tuli osaksi Chicagon koulukunnan tutkimusta 1920-luvulla. Kriminologi Eugene McLaughlin ja sosiologit David Downes ja Paul Rock ovat todenneet, että kaikista kaupungissa esillä olleista sosiaalisista ongelmista juuri rikollisuuden tutkimus korostui Chicagon sosiologien parissa ensinnäkin siksi, että tarve rikollisuutta hillitseville toimenpiteille oli suuri. Ongelman yhteiskunnallista merkittävyyttä korosti se, että niin vapaaehtoiset kuin kaupungin sosiaalityötä tekevät järjestötkin tukivat tutkimusta rahallisesti. Toinen syy oli yhdysvaltalaissosiologian alkuvaiheista asti näkynyt tutkijoiden taipumus käytännön ehdotusten tuottamiseen. Kuten edellä kävi ilmi, Chicagon sosiologit hyötyivät niin setlementtiliikkeen piirissä tehdystä kuin muustakin sosiaalityöstä kaupungissa. Kolmas syy oli mahdollisuus rikollisuuden konkreettiseen havainnointiin; jopa opiskelijat oli helppo lähettää havainnoimaan mitä kaduilla tapahtui (Downes ym., 2016, s. 55).

Sosiaalisen disorganisaation käsite esiintyi ensimmäisen kerran W. I. Thomasin ja Florian Znanieckin 5-osaisessa teoksessa The Polish Peasant in Europe and America (1918-1920/1984). ${ }^{7}$ Thomas kertoi myöhemmin, kuinka hän mietti kolmen eri etnisen ryhmän - italialaiset, juutalaiset ja puolalaiset - välillä, ja valinta kohdistui viime mainittuihin, vaikkei hän erityisemmin pitänyt puolalaisista ihmisinä (Bulmer, 1984, s. 47). Varsovassa hän tutustui nuoreen puolalaiseen filosofian koulutuksen saaneeseen Florian Znanieckiin, joka muutti Chicagoon juuri ennen ensimmäisen maailmansodan syttymistä.

\footnotetext{
${ }^{7}$ Tässä artikkelissa olemme käyttäneet vuonna 1984 julkaistua lyhennettyä versiota.
}

Kohta sen jälkeen Thomas palkkasi hänet assistentikseen kirjahanketta varten. Znanieckin rooli teoksen kirjoittamisessa oli hyvin vahva, ja häntä voi perustellusti pitää sen toisena tekijänä. Chicago oli tuolloin Varsovan ja Lodzin jälkeen maailman kolmanneksi suurin puolalaiskeskittymä (Bulmer, 1984, s. 48-50).

Thomas ja Znaniecki tutkivat Chicagoon siirtolaisina muuttaneiden puolalaisten sopeutumista uuteen kaupunkiin ja vieraaseen kulttuuriin. Teoksen yksi keskeinen menetelmällinen innovaatio oli niin sanottujen "egodokumenttien" käyttö: aineistona käytettiin elämäkertoja ja erityisesti kirjeitä (762 kirjettä). Näiden lähteiden avulla tekijät tarkastelivat puolalaisten siirtolaisten ryhmäsuhteita lähtötilanteessa ja maahanmuuton jälkeen sekä viitteitä siitä, mitä he kutsuivat sosiaaliseksi disorganisaatioksi. Käsitteellä tekijät tarkoittivat " a decrease of the influence of existing social rules of behavior upon individual members of the group" (Thomas \& Znaniecki, 1984, s. 191). Tämän vähenemisen historiallisena syynä oli perinteisten perheyhteisöjen hajoaminen ja uudelleen muotoutuminen siirryttäessä maatalousvaltaisesta yhteiskunnasta teolliseen yhteiskuntaan. Muutos näkyi niin yksilön normirikkomuksena kuin perheyhteisön tai laajemman instituution, kuten kirkon, yhtenäisyyden heikentymisenä. Sosiaalisen disorganisaation tilan vallitessa osa yhteisön jäsenistä pyrki tiukentamaan sosiaalista kontrollia ja palaamaan vanhaan järjestykseen. Useimmiten siihen palaaminen hajaannuksen jälkeen ei kuitenkaan ollut mahdollista, vaan yksilö tai yhteisö havaitsi muuttuneen sosiaalisen ympäristön myötä mahdollisuuden uudenlaiseen 
järjestäytymiseen. Tällöin perinteisten yhteisöjen harjoittama sosiaalinen kontrolli väheni, ja sosiaaliset suhteet ja rakenteet alkoivat muotoutua uudella tavalla. Kun yhteisön yhdenmukaisuus hajosi, yksilön suhtautuminen yhteisön arvoihin muuttui tai hänen elämässään saattoi esiintyä keskenään ristiriitaisia arvoja. Tämä hajaannuksen tila johti joko myönteisiin tai kielteisiin lopputuloksiin. Myönteinen sopeutuminen ilmeni, kun perheet ja yksilöt muodostivat uusia sosiaalisia verkostoja, esimerkiksi kaveruussuhteita, romanttisia suhteita, työtoveruuksia ja muita perheen ulkopuolisia suhteita. Epäonnistuneen sopeutumisen seurauksena syntyi puolestaan erilaisia sosiaalisia ongelmia, kuten "yksilön demoralisaatiota" ilmentäneet rikollisuus ja perheiden hajoaminen. Hajaannus ei ollut niinkään muutoksen varsinainen sosiaalinen syy kuin osa prosessia, jossa sosiaalisen elämän rakenteet muuttuivat yhteiskunnallisten muutosten myötä (Thomas \& Znaniecki, 1984, s. 76-79, 192, 193, 256-257).

Thomasille ja Znanieckille sosiaalisen disorganisaation tila oli siis hetkellinen, sillä hajaannuksen tila johti lopulta sosiaalisen elämän uudelleenjärjestymiseen, jonka seurauksena yksilöt sopeutuivat uudenlaiseen sosiaaliseen ympäristöön joko hyvin tai huonosti. Sosiaalisen disorganisaation käsite kuvasi vaihetta, jossa perinteinen, maatalousyhteiskunnissa vallinnut ja perheyhteisöihin perustunut sosiaalinen järjestelmä purkautui teollistumisen, kaupungistumisen ja siirtolaisuuden myötä. Yhtenäisyyttä koossapitävä sosiaalinen kontrolli ei tullut muutoksen jälkeen enää välttämättä perheyhteisöstä, vaan yhteiskunnan normit ja instituutiot, kuten oikeuslaitos, kontrolloivat yksilöiden toimintaa enemmän. Näin kävi tekijöiden mukaan juuri Yhdysvaltoihin muuttaneiden puolalaissiirtolaisten kohdalla. Thomasin ja Znanieckin teoksen tärkein anti sosiaalisen disorganisaation teorian kehittymiselle oli itse käsitteen luomisen lisäksi kaupunkisosiologialle hyvin relevantti selitys hajaannuksen taustalla vaikuttavista sosiaalisista, kulttuurisista ja psykologisista tekijöistä, jotka muuttivat arvoja ja asenteita ja lisäsivät sekä yksilöllisiä valinnan mahdollisuuksia että houkutuksia poiketa lain kaidalta tieltä.

Thomasin ja Znanieckin luoma sosiaalisen disorganisaation käsite vaikutti suoraan moniin Chicagon sosiologien teoksiin, mukaan lukien Nels Andersonin The Hobo (1923), Fredric Trasherin The Gang (1927), Ernest Mowrerin Family Disorganization (1927), Harvey Zorbaughin The Gold Coast and the Slum (1929), ja tässä artikkelissa esille tuleva Clifford R. Shaw'n ja Henry D. McKayn Juvenile Delinquency and Urban Areas (1942). Teoriaa sovellettiin myös mielenterveysongelmien sosiologisen tutkimuksen tarpeisiin: Ruth Shonle Cavan esitti itsemurhien runsaan esiintymisen syyksi sosiaalisen disorganisaation teoksessaan Suicide (1928), ja Robert E. L. Faris ja Henry Warren Dunham tarkastelivat Chicagon eri alueiden asukkaiden mielenterveyshäiriöiden ja sosiaalisen disorganisaation suhdetta uraauurtavassa teoksessaan Mental Disorders in Urban Areas (1939).

Thomasin ja Znanieckin työ sosiologian laitoksella kuitenkin päättyi Polish Peasant -teoksen kahden ensimmäisen osan ilmestymiseen vuonna 1918. Jo samana vuonna vapaamielisenä tunnettu Thomas erotettiin arveluttavin perustein ("seksiskandaali") yliopistosta. Thomas muutti New Yorkiin, minne myös Znaniecki siirtyi hänen perässään. New Yorkissa Thomas toimi vapaana tutkijana kirjoittaen muun muassa naispuolista nuorisorikollisuutta käsittelevän teoksen The Unadjusted Girl (1924). Hän myös jatkoi yhteistyötä Parkin kanssa Carnegie -yhtymän 
rahoittamassa Americanization Studies -hankkeessa, jossa pyrittiin koulutuksen avulla helpottamaan uusien maahanmuuttajien sopeutumista (Lagemann, 1992).

\section{Sosiaalinen disorganisaatio Chicagon kaupunkisosiologian teoriana}

Polish Peasant -teoksen ohella sosiaalisen disorganisaation käsite kehittyi kaupunkisosiologiseksi teoriaksi Robert E. Parkin ja Ernest W. Burgessin myötä. Vuonna 1921 Park ja Burgess julkaisivat sittemmin klassikon asemaan nousseen, kirjoittajien omien ja muiden kirjoittajien tekstejä julkaisseen ja niitä kommentoineen tuhatsivuisen teoksen Introduction to the Science of Sociology. Teoksessaan he määrittelivät sosiaalisen disorganisaation osaksi sosiaalisissa yhteisöissä tapahtuvia muutoksia. Heidän mukaansa yhteisössä havaittu disorganisaation tila ennusti tulevaa muutosta, joka johti sosiaalisen verkoston uudelleen järjestäytymiseen. Muutos ja toisaalta edistys eivät olleet mahdollisia ilman jonkinasteista hajaannusta. Varhaisia merkkejä sosiaalisen disorganisaation tilasta olivat lisääntynyt liikkuvuus ja levottomuus, pidemmälle edetessään taas rikollisuus ja sairauksien runsas esiintyvyys (Park \& Burgess, 1921, s. 55, 926).

Park ja Burgess jatkoivat käsitteen liittämistä kaupunkisosiologiseen viitekehykseen vuonna 1925 julkaistussa The City -teoksessa. Siinä heidän käsityksensä on yhtenevä Thomasin ja Znanieckin käsityksen kanssa sikäli, että sosiaalinen disorganisaatio on sosiaalista muutosta edeltävä normaali prosessi, joka voi pitkittyä ja muuttua haitalliseksi, ellei se johda onnistuneeseen uudelleenjärjestäytymiseen. Parkille ja Burgessille sosiaalinen disorganisaatio oli olennainen osa monimuotoista ja alati muuttuvaa kaupunkiympäristöä. Sen vastinparina yksilön tasolla oli yksilöllistymisprosessi (process of individualization), jonka vaikutuksesta perinteisen kulttuurin vaikutus ja sosiaalisen kontrollin järjestelmä heikkenivät. Kuten Chicagon aitiopaikalta ilmiötä seurannut Park totesi, "everything is in a state of agitation - everything seems to be undergoing a change" (Park \& Burgess, 2019, s. 107).

The City oli metodologisesti merkittävä teos, sillä Park ja Burgess tarkastelivat siinä kaupunkielämän säännönmukaisuuksia ihmisekologisen lähestymistavan ohjaamina (ekologisesta lähestymistavasta oli kirjassa oma, Parkin ja Burgessin oppilaan Roderick D. McKenzien kirjoittama luku). He myös kehittivät teoriaa ihmisryhmien ja kaupunkiympäristön välisen vuorovaikutuksen säännönmukaisuuksien tutkimiseksi. Ekologinen ajattelu oli Chicagon sosiologeille viitekehys, jonka avulla he tulkitsivat havaitsemiaan muutoksia ja ilmiöitä "kaupunkiorganismissa" ("ihmisekologiasta" ks. myös Park, 1936). Terminologia oli siis lainattu ekologiasta, mutta sen merkitys ei ollut täysin sama kuin luonnontieteissä (Lindner, 2006, s. 6772).

Burgess kuvasi omassa luvussaan kaupunkien laajentumista mallintamalla ne erilaisiin vyöhykkeisiin. Burgessin mallissa liike- ja teollisuuskeskustan ympärille kehittyi vyöhykkeitä, jotka eriytyivät toisistaan kaupungin kasvuprosessin edetessä. Keskeisen liikeja teollisuuskeskittymän ympärille muodostui niin sanottu muutosvyöhyke, jossa oli liiketoimintaa ja kevyttä teollisuutta. Seuraava eli kolmas vyöhyke koostui pääasiassa teollisuustyöväen asuinalueista. Alueet olivat siirtyneet keskustasta kohti kaupungin ulkokehää jatkuvasti uutta maa-alaa vallanneen teollisuuden tieltä. Neljännellä vyöhykkeellä sijaitsivat vakaat keskiluokkaiset asuinalueet, joiden sijaintiin tai rakenteeseen ei kohdistunut merkittäviä muutospaineita. Viidenneksi 


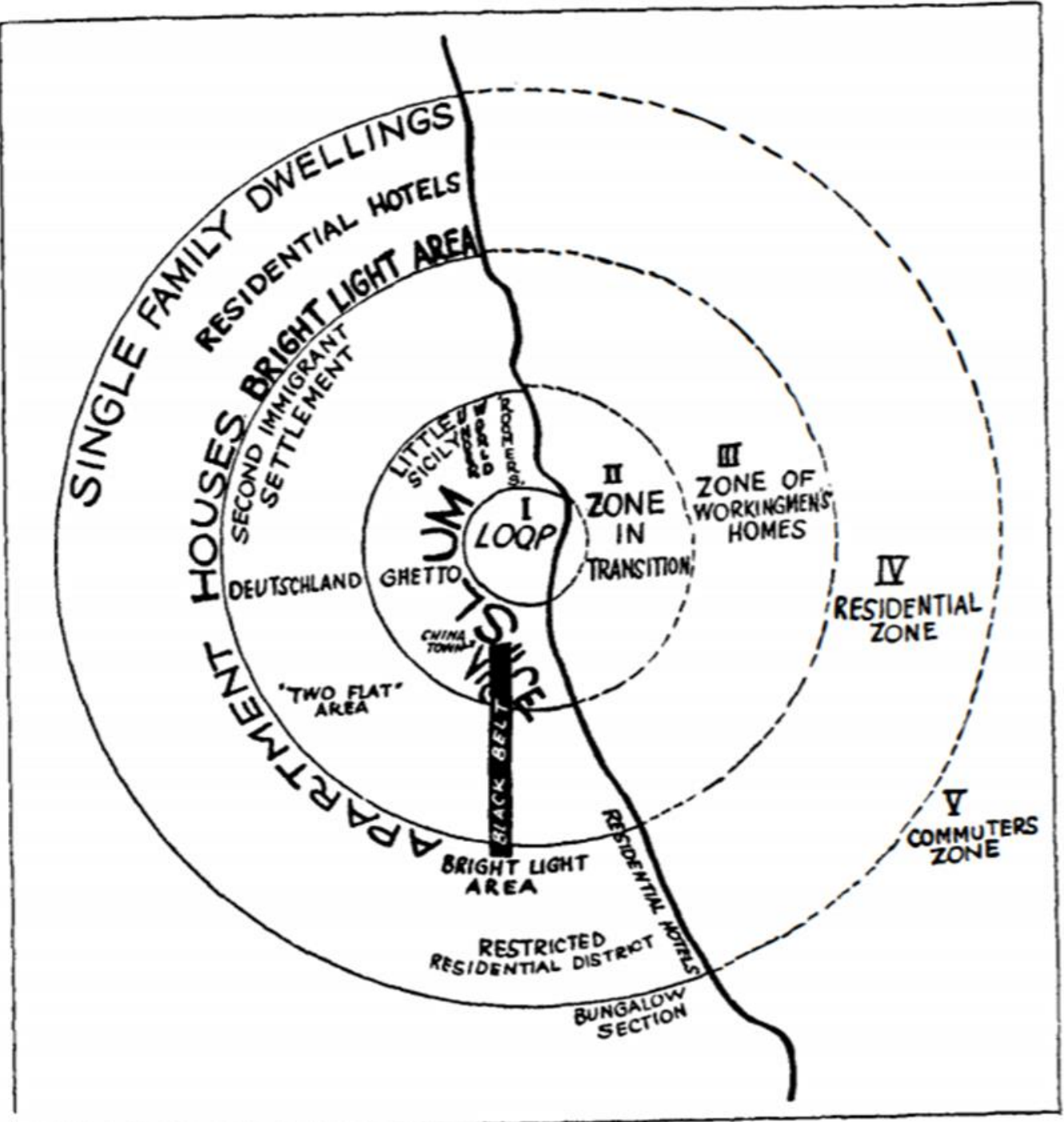

CHART II. Urban Areas

Kuva 1. Chicagon kaupunkivyöhykkeet 1920-luvulla Ernest Burgessin mukaan (Park \& Burgess, 2019, s. 55).

vyöhykkeeksi Burgess laski kaupungin liepeillä sijaitsevat satelliittikaupungit, joista kuljettiin töihin suurkaupunkiin. (Park \& Burgess, 2019, s. 50) Burgessin malli oli tarkoitettu sovellettavaksi nopeasti teollistuviin ja kasvaviin suurkaupunkeihin. Burgess havainnollisti mallia 1920-luvun Chicagoon sovelletulla kaaviolla (Kuva 1). Malli kuvaa asuinalueiden, väestönosien ja toimintojen sijoittumista eri vyöhykkeille. Keskellä piirrosta menevä linja merkitsee kaupungin ja Michigan-järven välistä rajaa.
Kolme keskeistä seikkaa selittävät sosiaalisen disorganisaation teorian nousua 1920-luvun Chicagossa: ensiksikin edellä mainittu saksalainen kaupunkisosiologia, joka innoitti tutkijoita tarkastelemaan kaupungin marginaali-ilmiöitä, ja toiseksi siirtolaisuuden aiheuttama Chicagon kaupunkirakenteen nopea kasvu ja muutos, josta setlementtiliike alkoi tuottaa tietoa 1890-luvulta alkaen. Kolmanneksi, tutkijoiden teoreettinen ja menetelmällinen kiinnostus antropologiaa, sosiaalipsykologiaa, maantiedettä ja evoluutioteoriaa kohtaan vaikutti tutkimuksen käytänteisiin ja sisältöön. Sosiaalinen disorganisaatio 
käsitteenä ja teoriana syntyi näiden käsitysten ja käytänteiden pohjalta kuvaamaan sitä, mitä kaupunkien sosiaalisissa verkostoissa tapahtui siirryttäessä maatalousvaltaisesta, perhekeskeisestä yhteiskunnasta teolliseen, yksilökeskeiseen ja markkinavoimien ohjaamaan yhteiskuntaan.

Chicagon sosiologien työ oli merkittävä myöhemmälle yhdysvaltalaiselle kaupunkisosiologiselle tutkimukselle, ja koulukunta antoi samalla vaikutteita muille tieteenaloille, kuten kriminologialle ja psykiatrialle. Sosiologien tutkimukset toimivat samalla voimakkaana vasta-argumenttina tuolloin varsin vaikutusvaltaiselle eugeeniselle liikkeelle, jonka edustajat selittivät köyhyyttä, rikollisuutta ja muita sosiaalisia ongelmia vähävaraisten sosiaaliryhmien ja niihin kuuluvien sukujen geneettisellä ala-arvoisuudella. Chicagon sosiologit osoittivat, että köyhyys, sairaudet, nuorisorikollisuus ja muut slummialueiden sosiaaliset ongelmat johtuivat sosiaalisesta disorganisaatiosta eikä niiden asukkaiden huonosta perimästä. (Faris, 1967, s. 57.)

\section{Sosiaalisen disorganisaation teoria varhaisessa kriminologiassa}

Clifford Shaw'n ja Henry McKayn teosta $J u$ venile Delinquency and Urban Areas (1942/1972) pidetään sosiaalisen disorganisaation teorian lähtöpisteenä kriminologiassa (Kubrin, 2010, s. 827-828). Teos on samalla myös kriminologian alueteoreettisen suuntauksen edelläkävijä. Siihen tiivistyi tekijöiden kahden vuosikymmenen tutkimuskokemus rikollisuuden alueellisesta jakautumisesta ja siihen vaikuttavista sosiaalisista tekijöistä (Short, 1972, s. xxv). Teoreettisesti $J u$ venile Delinquency perustui Parkin ja Burgessin ajatuksiin, erityisesti Burgessin vyöhykemalliin ja hypoteesiin rikollisuuden keskittymisestä muutosvyöhykkeelle. Tekijät pyrkivät tutkimuksellaan osoittamaan Burgessin hypoteesin oikeaksi: sosiaalisesti disorganisoituneella alueella yhteiskunnalliset rakenteet tuottivat rikollisuutta.

Shaw ja McKay tekivät vuosikymmenien ajan yhteistyötä Institute for Juvenile Research -instituutissa Chicagon Loop -alueella. Loop oli Burgessin vyöhykemalliin sijoitettuna sosiaalisesti disorganisoituneella muutosvyöhykkeellä. Sosiologit saattoivat siis kirjaimellisesti havainnoida katutason sosiaalisia ongelmia laitoksensa ikkunoista. Shaw’n ja McKayn välinen työnjako oli varsin selkeä: yhteiskunnallisesti aktiivinen, ehdonalaisen valvojana toiminut Shaw samastui rikollisten tarinoihin ja tähtäsi tutkimustyön avulla kuntouttavaan työhön nuorisorikollisten parissa. Akateemisesti orientoitunut McKay puolestaan keskittyi tilastojen tulkintaan ja karttojen luomiseen. (Snodgrass, 1976 , s. 2.) Shaw tarkasteli erityisesti nuorisorikollisten ongelmia, McKay rikollisuuden esiintymistä suhteessa rotuun ja etniseen taustaan. McKayn kiinnostus saattoi osaksi johtua hänen sukunsa lähihistoriasta, sillä hänen isoisänsä oli tullut Yhdysvaltoihin siirtolaisena Skotlannista. (Short, 1972, s. xlviii; Snodgrass, 1976, s. 5.)

Shaw ja McKay julkaisivat sekä yhdessä että erikseen useita teoksia ja artikkeleita. Erityisesti Shaw julkaisi nuorisorikollisuutta ja sen esiintyvyyttä tarkastelevia tutkimuksia, tunnetuimpina niistä The Jack-Roller: Delinquent Boy's Own Story (1930). Yksittäisten nuorisorikollisten elämää kuvaavien omaelämäkertojen kerääminen ja julkaiseminen oli Shaw'lle ja myös McKaylle tyypillistä erityisesti heidän tutkijanuransa alkuaikoina. Tätä pidetään nuorisorikollisuuden alueellista levinneisyyttä koskevan tutkimuksen ohella yhtenä heidän merkittävimmistä kontribuutioistaan sosiologiselle kriminologialle. (Snodgrass, 1976, s. 1.)

Vuonna 1929 Shaw ja McKay kollegoineen julkaisivat tutkimuksen Delinquency Areas, 
joka oli raportti 60 000:n rikoksista epäillyn nuoren miehen alueellisesta jakautumisesta Chicagossa. Heidän sijaintinsa kaupungissa määritettiin osoitetietojen perusteella. Kohdehenkilöt olivat virallisten tilastojen mukaan olleet tekemisissä kouluviranomaisten, poliisin tai oikeusistuinten kanssa. Kirjoittajat jakoivat heidät kolmeen ryhmään: koulupinnareihin (truants), nuorisorikollisiin (delinquent) ja järjestelmällisiin (aikuis)rikollisiin (criminal). Raportin perusteella näytti selvältä, että ryhmät jakautuivat paikallisesti. Epäillyt asuivat suurimmaksi osaksi köyhissä kaupunginosissa liike- ja teollisuuskeskittymien lähellä. Rikokset myös tapahtuivat näillä alueilla. Epäillyt asuivat harvoin muutosvyöhykkeen ja sen lähialueiden ulkopuolella. (Shaw \& McKay, 1972, s. 3.)

Shaw ja McKay osoittivat, että katu- ja nuorisorikollisuus näkyi Chicagon lisäksi myös muissa suurkaupungeissa, kuten Philadelphiassa ja Bostonissa. Vaikka kaupungit olivat rakenteeltaan ja luonteeltaan monessa suhteessa erilaisia, havainnot tukivat heidän teoriaansa rikollisuuden keskittymisestä sosiaalisesti disorganisoituneille alueille. (Ks. esim. Shaw \& McKay, 1972, s. 222-224, 254-255, 269-270.) He myös esittivät ihmisekologisen lähestymistavan mukaisesti, että katu- ja jengirikollisuus syntyi luonnollisena osana suurkaupungin kasvuprosesseja. Näitä prosesseja ei heidän mukaansa kyetty vielä kontrolloimaan, sillä niitä ei yksinkertaisesti vielä tunnettu. He toivat kaupungin kasvun aikana syntyvät alueelliset erot rikollisuuden esiintyvyyden tutkimuksen analyyttiseksi peruslähtökohdaksi. He tarkastelivat rikollisuutta sekä suhteessa kaupungin kasvuun että kaupunkielämän kompleksisuuteen. Tilastojen ja karttojen avulla he erottivat kaupungin alueita toisistaan niiden fyysisten ja taloudellisten piirteiden sekä väestörakenteen perusteella (Shaw \& McKay, 1972, s. 18, 42, 143). Kuten Burgess oli esittänyt, suurin osa rikoksista tapahtui teolli- suus- ja liikekeskittymissä tai niiden välittömässä läheisyydessä. Shaw ja McKay päättelivät, että teollisuuden tai liikealueen läheisyys vähensi näiden alueiden houkuttelevuutta. Tehtaiden tuottamat saasteet, äänet ja hajut saivat lähialueet vaikuttamaan likaisilta ja rumilta. Erityisesti teurastamoiden läheisyydessä ääni- ja hajuhaitat korostuivat. Nämä fyysiset tekijät laskivat alueen sosiaalista statusta, ja näiltä alueilta alkoi muuttoliike suuntautua ulospäin. (Shaw \& McKay, 1972, s. 143.)

Siirtolaisten liikkeiden tutkiminen paljasti kaupungin eri alueiden välisen muuttoliikkeen ja sosioekonomisen aseman välisen yhteyden. Siirtolaiset, jotka maahan tullessaan olivat yleensä köyhiä ja asettuneet ensin muutosvyöhykkeelle, muuttivat vaurastuttuaan tyypillisesti keskiluokkaisille esikaupunkialueille. Muutosvyöhykkeelle puolestaan muuttivat uudet siirtolaiset. Kuvio toistui, jolloin muutosvyöhyke säilyi köyhänä ja maahanmuuttajataustaisena samalla kun asukkaiden kansallisuus vaihteli. Näin kaupungin etninen rakenne ikään kuin eli omaa kiertokulkuaan. Rikollisuus ei siirtynyt ihmisten mukana alueelta toiselle, vaan keskittyi muutosvyöhykkeelle ja kytkeytyi sen rakenteisiin. Tilastojen perusteella asuinalueiden eriytyminen kulki rinnakkain asukkaiden taloudellisen aseman eroavuuksien kanssa. Halvat vuokrat pitivät köyhemmän väestönosan teollisuusalueiden läheisyydessä, kun taas paremmin toimeen tulevat pystyivät valitsemaan asuinalueekseen korkean sosiaalisen statuksen alueet, jotka sijaitsivat useimmiten kaupunkien laitamilla. Taloudellinen eriytyminen tarkoitti myös sitä, että eri alueilla asukkaiden ammatit ja työt erosivat toisistaan. (Shaw \& McKay, 1972, s. 21.)

Kun teollisuuden laajeneminen uhkasi asuinalueita, yksityisten toimijoiden toimenpiteet eivät riittäneet asuinalueen elvyttämiseen tai korjaamiseen, vaan siihen olisi vaadittu jul- 
kista avustusta, jota ei kuitenkaan ollut saatavilla. Tilannetta olisi voinut korjata yksityinen rahoitus, mutta sijoittajat eivät olleet kiinnostuneita luotaantyöntävistä alueista, joita leimasi jatkuva epävarmuus alueen maankäytöstä ja tulevaisuudesta. Paikalliset viranomaiset eivät ennättäneet vastaamaan nopeasti muuttuneisiin oloihin kaupunkisuunnittelulla, köyhimmät asukkaat jäivät rappeutuville alueille ja lopulta kynnelle kykenevät muuttivat pois. (Hillstrom, 2010, s. 11-12.) Tällainen varallisuuden perusteella tapahtuva prosessi toistui kaikissa kasvavissa suurkaupungeissa 1900-luvun alkupuolella, mikä johti sanontaan the city is dying at its heart. Teollisuuskaupunkien ytimet muuttuivat sosiaalisten ongelmien tyyssijoiksi (Shaw \& McKay, 1972, s. 20-21), ja yhdysvaltalaisten käyttöön tulivat samalla uudissanat slum ja inner city.

Shaw'n ja McKayn käsitys arvoista ja asenteista osana sosiaalista disorganisaatiota on yhtenevä Thomasin ja Znanieckin luoman käsitteen kanssa. Arvo ja asenne olivat muuttujia, jotka vaikuttivat sosiaalisen kontrollin toimivuuteen ja sen myötä yhteisöjen yhtenäisyyteen tai hajoamiseen. Heidän keskeinen havaintonsa oli se, että erityisesti perheiden lapsiin kohdistama sosiaalinen kontrolli oli sosiaalisesti disorganisoituneilla alueilla heikkoa ja ristiriitaista. Tämä selittyi Shaw’n ja McKayn mukaan osaksi juuri rikollisjengien ja -ryhmien tarjoamalla vaihtoehtoisella sosiaalisella yhteisöllä, joka vetosi nuoriin ja teki heistä lojaaleja näiden säännöille ja arvoille. Etenkin eurooppalaistaustaisten nuorten havaittiin usein ajattelevan, että oma perhe edusti vanhaa maailmaa, kun taas paikalliseen jengiin liittyminen teki heistä amerikkalaisempia. Siirtolaisnuoret saattoivat tuntea olevansa vahvasti kahden maailman välillä, jolloin uusi, kenties jännittävä ja stimuloiva paikallinen yhteisö vei mukanaan, mikä heikensi vanhempien kontrollia nuoriin. (Shaw \& McKay, 1972, s. 183-184.) Sosiologi Donald Shoemaker on esittänyt, että sosiaalisen disorganisaation teoria on kriminologiassa osaltaan sosiaalisen kontrollin teoria (Shoemaker, 2010, s. 101). Sosiaalisen kontrollin käsitteellä onkin Juvenile Delinquency -teoksessa keskeinen rooli sosiaalisen organisaation suojaamisessa hajaannukselta.

Shaw’n ja McKayn sosiaalisen disorganisaation teorian mukaan rikollisuuden taustalla olivat siis taloudellisten ja sosiaalisten resurssien epätasainen jakautuminen alueellisesti ja toisaalta näennäisesti kaikkien saatavilla olevat statussymbolit, mikä sai jotkut kokeilemaan onneaan laittomin keinoin ja myös yhdistämään voimansa eli jengiytymään. Erityisesti nuorten kohdalla vapaaaika yhdistettynä heikkoon sosiaaliseen kontrolliin antoi mahdollisuuden vahvistaa siteitä omiin sosiaalisiin viiteryhmiin. Väestön sosiaalisen ja alueellisen jakautumisen vuoksi rikollisuus ilmeni paikallisesti.

Shaw’n ja McKayn työ perustui osaltaan kriminologian keskeiseksi vaikuttajaksi nousseen Edwin Sutherlandin teoriaan systemaattisesta rikollisesta toiminnasta. Sutherland korosti ympäristön vaikutusta rikollisuuteen (Sutherland, 1947, s. 1-9). Sutherland ja McKay olivat tutustuneet Illinoisin yliopistossa, jossa Sutherland toimi 1920-luvulla opettajana ja jossa McKay vietti muutaman vuoden opiskellen ja itsekin opettaen (Snodgrass, 1976, s. 5). Todennäköisesti Sutherland sekä Shaw ja McKay vaikuttivat toistensa tutkimuksiin puolin ja toisin, erityisesti sosiaalisen disorganisaation teoriaan liittyen. Sutherlandin The Principles of Criminology teoksen (1924) uusitussa painoksessa (1939) sosiaalinen disorganisaatio esitetään yhtenä parhaista sosiaalisista selitysmalleista rikollisuuden esiintymiselle. Sutherland vertaa sosiaalista disorganisaatiota kipuun elimistössä. Siinä missä kipu ilmoittaa ihmiselle, että elimistössä jokin on pielessä, sosiaalinen disorganisaatio kertoo, että jokin on pielessä yhteisössä. (Sutherland, 1947, s. 8, 27.) 
Sosiaalisen disorganisaation teoria ei kuitenkaan lopulta ollut Sutherlandin mielestä tyydyttävä, ja hän kritisoi sittemmin sosiaalipatologista lähestymistapaa rikollisuuden tutkimiseen American Journal of Sociologyyn kirjoittamassaan artikkelissa (Sutherland, 1945). Hän korosti (myöhemmin artikkelissamme esille tulevan C. Wright Millsin tavoin) sosiaalisten normien suhteellisuutta. Sutherlandin mukaan disorganisoitunut yhteisö - kuten rikollisjengi - oli järjestäytynyt tavalla, joka konservatiivisesta näkökulmasta katsottuna oli patologinen. Kuten Kivivuori toteaa piilorikollisuuden löytämistä käsittelevässä teoksessaan, sosiaalipatologit eivät vaikuttaneet antavan painoarvoa "epänormaaliuden" kulttuurisille tai sosiaalisille tekijöille (Kivivuori, 2011, s. 38). Heidän mukaansa kaupunkien rakentuminen oli luonnollinen prosessi, jonka häiriytyessä syntyi sosiaalisen disorganisaation värittämiä alueita.

\section{Sosiaalinen disorganisaatio mustien asuttamilla alueilla}

Shaw'n ja McKayn mukaan huono-osaisuus ja sosiaalinen disorganisaatio leimasivat alueita, eivät tiettyjä kansallisia tai etnisiä ryhmiä. Tämä näkemys oli vastakkainen kriminologiassa 1800-luvun lopulla ja 1900-luvun alussa vallinneelle kriminaaliantropologiselle degeneraatioteesille, jonka mukaan rodun tai suvun parissa ilmenneet epämieluisat piirteet siirtyivät perimässä seuraaville sukupolville (Rafter, 2006, s. 159-163). Mustien asuttamat alueet, kuten vyöhykemallin mukainen Black Belt -alue Chicagossa, muodostivat tilastollisen poikkeuksen kaupungissa. Alueelta ei kohdistunut poismuuttoa vakaammille alueille samalla tavalla kuin eurooppalaissiirtolaisten asuttamilta alueilta. Väestö ei siellä vaurastunut kuten muu väestö, eikä alueelta tapahtunut siirtymää vakaammille alueille ajan myötä. Yleisen mallin vastaisesti mustien asuttaman alueen väestö kasvoi tilanteessa, jossa se olisi muualla vähentynyt. Päinvastainen tilanne johtui siitä, että mustien liikkumista rajoitettiin. Etelävaltioiden kaupungeissa toistui samanlainen kuvio, mutta sitä ylläpitivät Shaw'n ja McKayn hieman sievistelevin sanoin "erityyppinen normijärjestelmä ja tabut" (Shaw \& McKay, 1972, s. 22). Etelässä elettiin tuolloin tiukkaa rotusyrjintää ylläpitäneiden Jim Crow -lakien aikaa. Vaikka olot saattoivat olla suotuisammat pohjoisen teollisuuskaupungeissa, eivät mustat suinkaan olleet tasavertaisia muun väestön kanssa sielläkään (Lewis \& Lewis, 2009, s. 43, 102-103). Mustien heikko asema niin työmarkkinoilla kuin yhteiskunnassa laajemmin vaikutti siihen, että he muodostivat poikkeuksen Shaw'n ja McKayn esittämään kiertokulkuun, joka koski Euroopasta tulleita siirtolaisia.

Myös rikostilastoissa mustien määrä säilyi korkeana vuodesta toiseen. Tämä havainto oli hankala sosiaalisen disorganisaation teorian toimivuuden kannalta, sillä yhden väestöryhmän pysyvästi suuri määrä tilastoissa haastoi käsityksen siitä, ettei rikollisuus kytkeytynyt yksittäisiin etnisiin ryhmiin. Teorian vaarantumisen lisäksi tämä anomalia oli ongelmallinen siksi, että sen myöntäminen olisi tarkoittanut avoimesti kriittisen näkemyksen omaksumista yhdysvaltalaiseen yhteiskuntaan ja sen rodulliseen segregaatioon. (Snodgrass, 1976, s. 5.) Shaw ja McKay tosin löysivät mustien asuinalueiden sisältä samanlaista hajontaa kuin yleensä kaupungin sisällä: alemman vuokratason alueilla ilmeni enemmän rikollisuutta kuin korkeamman vuokratason alueilla (Shaw \& McKay, 1972, s. 148). Mustat eivät näin ollen muodostaneet sikäli poikkeavaa ryhmää, että heidän rikollisuutensa olisi ollut jotenkin sisäsyntyistä, vaan anomaliaa selitti yksinkertaisesti rotusyrjintä. 
Juvenile Delinquency -teoksessa esitetty havainto siitä, ettei rikollisuus ilmennyt yksittäisen kulttuurisen ryhmän ominaispiirteenä, vaikutti myöhempiin poikkeavuuksia selittäviin sosiologisiin teorioihin, kuten sosiaalisen disorganisaation teoriaa ja sosiaalista paineteoriaa mukailevaan poikkeavuutta kulttuurisena ilmiönä tarkastelevaan teoriaan (cultural deviance theory). Teorian mukaan asuinalueen ominaisuudet ja paikalliskulttuuri vaikuttavat yksilöön, ja alueellisten olojen jatkuvuus siirtää paikallisen normiston ja arvomaailman sukupolvelta toiselle. (Gottfredson \& Hirschi, 1990, s. 81-82.)

\section{Sosiaalireformistinen kriminologia}

Shaw'lle ja McKaylle oli merkityksellistä, että heidän esittämiään tuloksia voitiin käyttää rikollisuuden ennaltaehkäisyyn. Akateeminen tutkimus ilman käytännön toimintaan tähtäävää tavoitetta ei heidän mukaansa palvellut muita kuin tutkijoita. Sosiologisen tutkimuksen tuli pyrkiä yhteiskunnan heikommassa asemassa olleiden, erityisesti nuorten rikollisten, konkreettiseen auttamiseen (Shaw \& McKay, 1972, s. 4-5). Shaw'1la ja McKaylla oli selkeä sosiaalireformistinen tavoite, ja he pyrkivätkin löytämään uusia kontrollikeinoja nuorisorikollisuuden kitkemiseen (Tonry, 2013, s. 10).

Rikollisuutta tuli Shaw'n ja McKayn mukaan pyrkiä vähentämään kohdistamalla resursseja sinne, missä ongelmat esiintyivät. He kiinnittivät huomiota yhteiskunnan perinteisiin arvoihin pohjaavan sosiaalisen toiminnan ja järjestäytymisen tarpeeseen hajaantuneilla alueilla. Tutkimustulostensa perusteella he katsoivat, että rikollisongelman hoito suurissa kaupungeissa vaati paikallisyhteisöjen olojen parantamista, eikä näin ollen pelkällä yksilön diagnosoinnilla ja valvonnalla ollut riittävää vaikutusta (Shaw ja McKay, 1972, s. 4-5). Shaw’n ja McKayn ajattelussa sosiaali- nen disorganisaatio oli siis vahvasti kytköksissä paikallisiin rakenteisiin ja instituutioihin. Sosiaalireformistinen painotus liitti heitä setlementtiliikkeseen, mikä ei suinkaan ollut sattumaa: Shaw oli toiminut nuorisotuomioistuimen palveluksessa ehdonalaisvalvojana, ja tuomioistuimen perustajina olivat olleet setlementtiläiset.

Shaw'n yksi käytännön toimenpide oli $C h i$ cago Area Project -ohjelman perustaminen vuonna 1931. Ohjelma pyrki tavoittamaan nuoria heidän omassa ympäristössään ja luomaan turvallisia paikallisyhteisöjä ja ohjausta rikollisuuteen alttiille ja jo rikoksista tuomituille nuorille. Shaw'n mukaan nuorten potentiaali tuli kanavoida rakentavasti sen tukahduttamisen ja marginalisoinnin sijaan (Short, 1972, s. xlvi-xlviii). Vaikka rikolliseksi ajautuivat yleensä siirtolaistaustaiset nuoret, rikollisuus ei kuitenkaan selittynyt etnisillä tai kansallisilla ominaisuuksilla, vaan alueellisilla olosuhteilla ja köyhien alueiden asukkaiden heikoilla lähtökohdilla. Teorian perusteella sosiaalisesti disorganisoituneella alueella kasvaminen olisi siis voinut tehdä kenestä tahansa varkaan. Tämän torjumiseksi Shaw ja McKay ehdottivat harkittuja interventioita ongelma-alueilla. Rangaistuslaitoksiin rikollisuuden torjunnassa he eivät uskoneet, sillä ne olivat tutkimusaineiston perusteella osoittautuneet lähinnä rikollisuuden oppilaitoksiksi.

\section{Sosiaalisen disorganisaation teoria 1940-luvulta 1960-luvulle}

Sosiaalisen disorganisaation teoria oli 1940luvun aikana jo varsin laajassa käytössä. Teorian soveltamisalueet alkoivat näyttäytyä aikakauden sosiaalisten ongelmien listalta. Esimerkiksi Chicagon koulukunnan kasvatti Robert E. L. Faris kirjoitti laajan kurssikirjaksi tarkoitetun teoksen sosiaalisesta disorganisaatiosta (1948). Siinä hän sisällytti useita "sosiaalisia ongelmia" käsitteen alle: oman 
lukunsa saivat niin rikollisuus, itsemurha, paheet (kuten alkoholismi, prostituutio ja uhkapelaaminen) ja "mentaaliset epänormaaliudet", ja näiden lisäksi hän käsitteli henkilökohtaista disorganisaatiota (personal disorganization), disorganisaatiota taloudessa, politiikassa (korruptio), uskonnollisissa instituutioissa ja perheissä, ja oman lukunsa saivat myöskin "massakäyttäytymisen ja joukkoväkivallan (mob violence)" häiriöt.

Rikollisuudesta Faris ei esitä mitään uutta teoreettisesti tai rikollisuuden vastaiseen työhön soveltuen. Hän lähinnä kuvaa muiden rikollisuuden tutkijoiden tutkimuksia, mukaan lukien Sutherland ja tämän tutkimus valkokaulusrikollisuudesta sekä Shaw ja McKay, joiden Juvenile Delinquency -teosta hän pitää johtavana kaupunkialueiden ja erityisesti slummien nuorisorikollisuustutkimuksena (Faris, 1948, s. 128). Yhteistä Farisille ja edellä mainituille kriminologeille oli psykologisten ja psykiatristen selitysten hylkääminen. Kuten Faris toteaa, mahdollisella henkilökohtaisella epänormaaliudella ei ole merkitystä rikollisuuteen johtavissa prosesseissa. Olennaista sen sijaan on sosiaalisen kontrollin "normaalien mekanismien rikkoutuminen", mistä jo sosiaalisen disorganisaation käsitteen lanseeraajat olivat puhuneet (Faris, 1948, s. 161). Farisin kirja paljastaa sosiaalisen disorganisaation teorian ongelman: siitä oli 1940-luvun loppuun mennessä tullut liian yleisluontoinen, löysästi määritelty ja kaikkiin mahdollisiin sosiaalisiin "patologioihin" sovellettu käsite, jonka analyyttinen hyöty alkoi olla kyseenalainen.

Teoriaa ja laajemmin amerikkalaisia "sosiaalipatologeja" vastaan hyökkäsi nuori, vastikään väitellyt sosiologi C. Wright Mills American Journal of Sociologyssa vuonna 1943. Suorapuheinen Mills näki sosiaalisen disorganisaation ja vastaavien, eksplisiittisesti epäselvien ja implisiittisesti konservatiivisten käsitteiden, kuten "sosiaalinen sopeu- tuminen" (social adjustment) ja "sosialisaatio", ilmentävän ennemminkin niitä käyttävien sosiaalitieteilijöiden nostalgista "smalltown America" -ideologiaa kuin yhteiskunnallista todellisuutta. Mills suomi vanhempia kollegoitaan heidän ajattelunsa matalasta abstraktiotasosta, kyvyttömyydestä kyseenalaistaa "poikkeavuuden" käsitettä tai antaa tarkkoja määritelmiä "sosialisaation" kaltaisille avaintermeille, taipumuksesta ottaa sosiaaliset normit annettuina ja keskittyä yksilöihin ja jättää samalla yhteiskunnan rakenteet kriittisen tarkastelun ulkopuolelle. Äkilliset tai jopa vallankumoukselliset muutokset joko jätetään huomioimatta tai niitä pidetään patologian merkkeinä, jälkimmäisinä erityisesti silloin kun kyseessä ovat (suur)kaupunkiympäristössä tapahtuvat muutokset. Mills kärjistää "sosiaalipatologien" ajattelun näin: "what a conservative calls disorganization, a radical might well call reorganization." (Mills, 1943, s. 178). Itse asiassa Park, Burgess ja muut varhaiset Chicagon sosiologit olivat juuri näitä Millsin kuvaamia radikaaleja: he näkivät kaupunkien kasvun hajaannuksen (disorganization) ja uudelleenjärjestymisen (reorganization) prosessina (Park \& Burgess, 2019, s. 54).

Millsin tarkastelemasta yli 30 "sosiaalipatologista" ei yksikään ollut ainakaan suoraan luokiteltavissa Chicagon sosiologiksi; näin ollen hän ei myöskään käsittele esimerkiksi Shaw'n ja McKayn yhdessä tai erikseen kirjoittamia julkaisuja. Millsin kärkevä kritiikki ei kuitenkaan ollut perusteetonta, ja esimerkiksi Farisin Social Disorganization -teoksessa on helposti nähtävissä Millsin osoittamia ongelmia, vaikkei Faris varmasti ollut amerikkalaissosiologian aatteellisella kentällä "taantumuksellisemmasta" päästä. Yhtä kaikki, Fariskin näyttäytyy teoksessaan konservatiivisia ihanteita kannattelevan pikkukaupunki-Amerikan edustajana, jolle sosiaalinen disorganisaatio oli ennen kaikkea suurkaupunkien ja niiden slummien ongelma. 
1960-luvun alussa sosiologi Daniel Bell joka oli opettanut Chicagon yliopistossa 1940-luvun lopulla - kritisoi The End of Ideology -teoksessaan sosiaalisen disorganisaation käsitteen käyttöä oman aikansa Yhdysvalloissa, jossa esimerkiksi rikollisuus ja väkivalta olivat vähentyneet (1960-luvulla molemmat kääntyivät nousuun). Bell väittää, että samalla kun Yhdysvalloissa sosiaalinen ja kulttuurinen muutos on "luultavasti laajempaa ja nopeampaa kuin missään muussa maassa", se ei kuitenkaan tarkoita, että oletus suuren muutoksen aiheuttamasta sosiaalisesta epäjärjestyksestä (disorder) ja anomiasta pitäisi paikkaansa. (Bell, 1988, s. 37.) Bellin kriittinen näkemys siitä, että aika on ajanut sosiaalisen disorganisaation käsitteen ohi ja tehnyt siitä epärelevantin, oli 1960-luvulle tultaessa yleistynyt yhdysvaltalaisessa sosiologiassa. Ainakaan kahdessa 1960-luvulla julkaistussa laajassa sosiologian yleisteoksessa ei ole edes viittauksia sosiaaliseen disorganisaatioon (Lazarsfeld ym., 1967; Merton, 1968). Yksi mahdollinen syy teorian hiipumiseen Yhdysvalloissa oli sen kohteen eli kaupunkien kasvun hiipuminen 1960-luvulla "post-industrialistisen" ja esikaupungistuneen aikakauden myötä (Bellair, 2017, s. 2). Toisaalta kaupunkikeskustojen (osittainen) autioituminen ja slummiutuminen tekivät mustien kansalaisoikeustaistelujen ja kaupunkimellakoiden 1960-luvusta kaupunkisosiologisesti hyvin merkittävän ajanjakson.

Teorian marginalisointiin 1960-luvulla vaikutti koko Chicagon vanhentuneeksi koetun koulukunnan maineen lasku, mitä vahvisti yhdysvaltalaissosiologiassa yleistynyt virheellinen käsitys Robert E. Parkista rasistina tai vähintään "rodullisen essentialismin" edustajana (Athens, 2020; myös suomalaisessa rasismin historiaa käsittelevässä teoksessa kuvataan Parkia "biologisen ja essentialistisen" rotukäsityksen edustajana; ks. Isaksson \& Jokisalo, 2005, s. 90-91). Nykytermein ilmaistuna, Parkista ja Chicagon (varhaisesta) koulukunnasta tuli akateemisessa yhdysvaltalaissosiologiassa "toksisia", väärin perustein kylläkin. Kriminologiassa sosiaalisen disorganisaation teoria tuli uudelleen esille 1980-luvulla (ks. esim. Wilson, 1987 ja Sampson \& Groves, 1989).

\section{PÄÄTELMÄT}

Sosiaalisen disorganisaation käsitteestä kehittyi yhteiskuntatieteiden (sosiologia, sosiaalipsykologia, kriminologia, sosiaalityö) tieteenalojen tutkimustarpeisiin soveltuva teoria maailmansotien välisen ajan Yhdysvalloissa. Rajasimme artikkelimme Chicagon sosiologisen koulukunnan piirissä tehtyihin tutkimuksiin, koska ne vaikuttivat ylivoimaisesti eniten sosiaalisen disorganisaation teorian kehittymiseen. Aihetta kuitenkin käsittelivät varsinkin 1930-luvulla myös muiden yliopistojen sosiologit (ks. esim. Elliott \& Merrill, 1934). Aihepiirejä myös yhdisteltiin, minkä myötä tutkijat tarkastelivat esimerkiksi mielenterveyshäiriöiden ja rikollisuuden suhdetta sosiaalisesti disorganisoituneilla alueilla.

\section{Teorian syntyyn ja kehittymiseen vaikuttaneet tekijät}

Sosiaalisen organisaation teoriasta tuli suosittu, koska sen avulla kyettiin antamaan uskottavia sosiologisia selityksiä (suur)kaupunkien kasvun ja muutoksen tuomista ongelmista. Teoria muotoutui erityisesti kriminologiaan soveltuvaksi siksi, että se näytti olevan oman aikansa empiirisesti toimivin sosiologinen selitysmalli rikollisuuden, erityisesti katu- ja nuorisorikollisuuden, esiintymisestä. Juuri nuorisorikollisuuden tutkimista pidettiin yhteiskunnallisesti merkittävänä, sillä rikollisuuden kontrolloimiseen pyrittiin löytämään keinoja selvittämällä syitä nuorten tekemille rikoksille. Erityisesti Shaw'n ja 
McKayn teoria tarjosi sekä toimivan rikollisuuden selitysmallin että konkreettisia ratkaisuehdotuksia.

Teorian synnyn ja kehittymisen eksternalistinen selitys on nähdäksemme 1900-luvun alkuvuosikymmenien voimakas kaupungistuminen, johon vaikuttivat ennen kaikkea maahanmuutto ja maan sisäinen muuttoliike, erityisesti ns. Great Migration eli mustien etelävaltiolaisten massamuutto pohjoisten osavaltioiden teollisuuskeskuksiin ensimmäisen maailmansodan aikana ja heti sen jälkeen. Chicagon valtavan nopea kasvu oli juuri näiden kahden muuttoliikkeen aiheuttamaa. Kaupungistumisen sosiaalisiin ongelmiin oli alettu kiinnittää huomiota journalistien, setlementtien ynnä muiden progressiivisen kauden vaikuttajien parissa, ja erityisesti setlementtiliike vaikutti voimakkaasti Chicagon sosiologiaan. Kun Hull Housen setlementtiaktivistien kanssa yhteistyötä tehnyt W. I. Thomas kiinnostui 1910-luvulla puolalaisten maahanmuuttajien sopeutumisesta suurkaupungiksi kasvaneeseen Chicagoon, otettiin ensimmäinen ratkaiseva askel kohti etnografiaa, ihmisekologiaa ja sosiaalipsykologiaa yhdistelevää urbaanisosiologiaa, jonka yhdeksi keskeiseksi käsitteeksi nousi sosiaalinen disorganisaatio.

Teorian selkeämmin internalistisena selittävänä tekijänä voi pitää Chicagon sosiologisen tutkimuksen kiinnittymistä kiihkeässä muutoksen tilassa oleviin suurkaupunkeihin, lähinnä Chicagoon. Tutkijat havainnoivat kaupungin eri alueilla erilaisia järjestyksen ja epäjärjestyksen asteita, ja sosiaaliset ongelmat näyttivät olevan suorassa yhteydessä jälkimmäiseen eli disorganisaatioon. Selkeimmin tämä yhteys näkyi rikollisuudessa, mutta myös muun muassa mielisairauksien ja avioerojen jakautumisessa eri asuinalueisiin (Abbott, 1999, s. 201). Chicagon sosiologien ekologinen tutkimus kohdistui kaupunkialueiden sosiaalisiin rakenteisiin ja näiden ra- kenteiden muuttumiseen. Toisin sanoen, sosiaalisia ilmiötä on mielekästä tutkia vain ajallisten muutosten kautta, siis diakronisesti - puhdas synkroninen rakenne- ym. sosiaalitutkimus loistaa poissaolollaan Chicagon sosiologiassa, samoin raskas teoreettinen apparaatti.

Thomasin ja Znanieckin teoksen ohella oli johtavien Chicagon sosiologien Parkin ja Burgessin työllä olennainen vaikutus sosiaalisen disorganisaation käsitteen leviämiselle, sillä he ikään kuin sijoittivat käsitteen konkreettisesti Chicagon kartalle. Sosiaalinen disorganisaatio ei heidän myötään ollut enää ainoastaan sosiaalisissa verkostoissa esiintyvä hetkellinen tila ennen uudelleenorganisoitumista, vaan se oli pysyvä ilmiö, joka oli alueellisesti havaittavissa ja tutkittavissa. Tämä oli se viitekehys, jossa sosiologit alkoivat enenevissä määrin hyödyntää sosiaalisen disorganisaation käsitettä omissa tutkimuksissaan. Chicagon koulukunnan ensimmäisen sukupolven tutkimuksilla ja opetuksella oli merkittävä vaikutus koulukunnan seuraavan sukupolven tutkijoihin, joista kriminologian kehitykselle keskeisimpiä olivat Clifford R. Shaw ja Henry D. McKay.

\section{Chicagon koulukunta, Heikki Waris ja suomalainen aluetutkimus}

Suomessa teoriaa on sovellettu vain vähän, sillä perinteisesti kaupunkiemme koko ei ole soveltunut teorian käyttöön - meillä ei ole Chicagoa. Suomalaisen sosiaalipolitiikan tutkimuksen pioneeri Heikki Waris sai kuitenkin Chicagon koulukunnalta vaikutteita kirjoittaessaan väitöskirjaansa Työläisyhteiskunnan synty Pitkänsillan pohjoispuolella (1932; toinen osa 1934). Vuonna 1934 Waris vieraili Rockefeller-säätiön stipendiaattina Chicagon sosiologian laitoksella, jossa hän osallistui Ernest W. Burgessin seminaareihin ja luentokursseille. Koulukunnan tutkimuksesta inspiroituneena hän keräsi suomalaisilta 
maahanmuuttajilta elämäkerta-aineistoa, jota hän ei kuitenkaan koskaan hyödyntänyt (Lindberg, 2014, s. 49-50). Kuten sosiaalipolitiikan emeritusprofessori J.P. Roos on todennut, Chicagon sosiologian vaikutus näkyi sotien jälkeen Wariksen johtamassa laajassa siirtokarjalaisten sopeutumista käsittelevässä hankkeessa (Roos, 2021; Waris ym., 1952).

Sosiaalisen disorganisaation teorian historian tuntemus on nähdäksemme hyödyllinen kriminologialle muun muassa teoriaan sisään rakennetun alueteoreettisen lähestymistavan myötä. Teoriaa käytetään edelleen etenkin kansainvälisessä kriminologiassa, psykiatriassa ja kaupunki- ja aluetutkimuksessa. Yksi tuore suomalaistutkimus, jossa sosiaalisen disorganisaation teoriaa on hyödynnetty viitekehyksenä, on sosiologi Lotta Junnilaisen väitöskirja Lähiökylä. Tutkimus yhteisöllisyydestä ja eriarvoisuudesta (2019). Kuten Junnilainen toteaa, kansainvälinen kaupunkisosiologinen tutkimusperinne voi tulevaisuudessa tarjota hyödyllisiä näkökulmia myös suomalaiseen aluetutkimukseen, jossa kaupunkisosiologinen tutkimusperinne tunnetaan toistaiseksi huonosti (Junnilainen, 2019, s. 25). Teorian historian tuntemus lisää samalla alueteoreettisen tutkimuksen tuntemusta, jolle on käyttöä edelleen kaupungistuvassa Suomessa.

\section{KIRJALLISUUS}

Abbott, A. (1999). Department \& Discipline: Chicago Sociology at One Hundred. Chicago: University of Chicago Press.

Addams, J. \& Residents of Hull-House (1895). Hull-House Maps and Papers: A Presentation of Nationalities and Wages in a Congested District of Chicago, Together with Comments and Essays on Problems Growing Out of the Social Conditions. New York: Thomas Y. Crowell \& Co.

Athens, L. (2020). The Renunciation of Robert E. Park: Myths about his Sociological Work. The American Sociologist, 51, 76-91. https://doi.org/10.1007/s12108-01909430-3

Baker, P.J. (1973). The Life Histories of W. I. Thomas and Robert E. Park. American Journal of Sociology, 79(2), 243-260. https://doi.org/10.1086/225545

Bell, D. (1988). The End of Ideology (1. painos 1960). Cambridge, MA: Harvard University Press.

Bellair, P. (2017). Social Disorganization Theory. Oxford Research Encyclopedias, Criminology and Criminal Justice. Oxford: Oxford University Press. https://doi.org/10.1093/acrefore/9780190264079.013.253

Boydell, J. \& Murray, R. (2003). Urbanization, Migration and Risk of Schizophrenia. Teoksessa R. Murray, P. Jones, E. Susser, J. van Os, \& M. Cannon (toim.), The Epidemiology of Schizophrenia (s. 49-73). Cambridge: Cambridge University Press.

Bulmer, M. (1984). The Chicago School of Sociology. Institutionalization, Diversity, and the Rise of Sociological Research. Chicago: The University of Chicago Press. 
Carey, J. T. (1975). Sociology and Public Affairs: The Chicago School. Beverly Hills, CA: Sage.

Cullen, F. T. \& Wilcox, P. (toim.) (2010). Encyclopedia of Criminological Theory. Thousand Oaks, CA: Sage Publications, Inc.

https://dx.doi.org/10.4135/978141295919 3

Deegan, M. J. (1981). Early Women Sociologists and the American Sociological Society: The Patterns of Exclusion and Participation. The American Sociologist, 16(1), 14-24.

Deegan, M. J. (1988). W.E.B. Du Bois and the Women of Hull-House, 1895-1899. The American Sociologist, 19(4), 301311.

Deegan, M. J. (2005). A Private Trouble Behind the Gendered Division of Labor in Sociology: The Curious Marriage of Robert E. Park and Clara Cahill Park. Teoksessa A. J. Blasi (toim.), Diverse Histories of American Sociology (s. 18-39). Leiden: Brill.

Downes, D., Rock, P., \& McLaughlin, E. (2016). Understanding Deviance (7. painos). Oxford: Oxford University Press.

Elliott, M. A. \& Merrill, F. E. (1934). Social Disorganization. New York: Harper \& Brothers.

Faris, R. E. L. (1948). Social Disorganization. New York: The Ronald Press Company.

Faris, R. E. L. (1967). Chicago Sociology: 1920-1932. San Francisco: Chandler.

Fritzsche, P. (1994). Vagabond in the Fugitive City: Hans Ostwald, Imperial Berlin and the Großstadt-Dokumente. Journal of Contemporary History, 29(3), 385-402.

Gottfredson, M. R. \& Hirschi, T. (1990). A General Theory of Crime. Stanford: Stanford University Press.

Grant, L., Stalp, M.C., \& Ward, K. B. (2002). Women's Sociological Research and Writing in the AJS in the Pre-World War II Era. The American Sociologist, 33(3), 69-91.

Helo, A. \& Pietikäinen, P. (2017). Aatehistorian merkitys ja välineet. Teoksessa M. Myllykangas \& P. Pietikäinen (toim.), Ajatusten lähteillä. Aatteiden ja oppien historiaa (s. 21-26). Helsinki: Gaudeamus.

Hillstrom, L. C. (2010). The Muckrackers and the Progressive Era. Detroit: Omnigraphics.

Jazbinsek, D., Joerges, B., \& Thies, R. (2001). The Berlin Großstadt-Dokumente: A Forgotten Precursor of the Chicago School of Sociology. WZB Discussion Paper, No. FS II 01-502. Wissenschaftszentrum Berlin für Sozialforschung.

Johnson, C. \& Sautter, R. C. (1994). Wicked City Chicago: From Kenna to Kapone. Highland, IL: December Press.

Isaksson, P. \& Jokisalo, J. (2005). Kallonmittaajia ja skinejä: rasismin aatehistoriaa (3. painos). Helsinki: Like/Suomen rauhanpuolustajat.

Junnilainen, L. (2019). Lähiökylä. Tutkimus yhteisöllisyydestä ja eriarvoisuudesta. Tampere: Vastapaino.

Kivivuori, J. (2011). Discovery of Hidden Crime. Self-Report Delinquency Surveys in Criminal Policy Context. New York: Oxford University Press. https://doi:10.1093/acprof:osobl/9780199639199.001.0001

Kivivuori, J., Aaltonen, M., Näsi, M., Suonpää, K., \& Danielsson, P. (2018). Kriminologia. Rikollisuus ja muuttuva kontrolli yhteiskunnassa. Helsinki: Gaudeamus.

Kubrin, C.E. (2010). Shaw, Clifford R., and Henry D. McKay: Social Disorganization Theory. Teoksessa F. T. Cullen \& P. Wilcox (toim.), Encyclopedia of Criminological Theory (s. 827-834). Thousand Oaks, CA: Sage Publications. 
Kurtz, L. R. (1984). Evaluating Chicago Sociology: A Guide to the Literature, with an Annotated Bibliography. Chicago: The University of Chicago Press.

Lagemann, E. C. (1992). The Politics of Knowledge. The Carnegie Corporation, Philanthropy, and Public Policy. Chicago: The University of Chicago Press.

Laine, M. (2007). Kriminologia ja rankaisun sosiologia. Helsinki: Tietosanoma.

Lazarsfeld, P. F., Sewell, W. H., \& Wilensky, H. L. (1967). The Uses of Sociology. New York: Basic Books.

Lewis, C. M. \& Lewis, J. R. (2009). Jim Crow America: A Documentary History. Fayetteville: The University of Arkansas Press.

Lindberg, H. (2014). Mannen som objekt och problem: Heikki Waris och betydelsen av kön I vetenskaplig socialpolitik, ca 1930- 1970. Åbo: Åbo Akademis förlag. Noudettu osoitteesta urn.fi/URN:ISBN:978-951-765-739-6

Lindner, R. (2006). The Reportage of Urban Culture. Robert Park and The Chicago School. [Alkup. Die Entdeckung der Stadtkultur: Soziologie aus der Erfahrung der Reportage (1990), käänt. A. Morris (1996)]. Cambridge: Cambridge University Press.

Manninen, J. (2004). Puheenvuoroja aateja oppihistoriasta. Oulu: Sophopolis.

Merton, R. K. (1968). Social Theory and Social Structure. New York: Free Press.

Mills, C. W. (1943). The Professional Ideology of Social Pathologists. American Journal of Sociology, 49(2), 165-180.

Park R. E. (1915). The City. Suggestions for the Investigation of Human Behavior in the City Environment. American Journal of Sociology, 20(5), 577-612. https://doi.org/10.1086/212433

Park R. E. (1928). Human Migration and the Marginal Man. American Journal of Sociology, 33(6), 881-893. https://doi.org/10.1086/214592
Park, R. E. (1936). Human Ecology. American Journal of Sociology, 42(1), 1-15. https://doi.org/10.1086/217327

Park, R. E. (1939). Review of Milla A. Alihan, Social Ecology. Annals of the American Academy of Political Science, 202, 264-265.

Park, R. E. \& Burgess, E. W. (1921). Introduction to the Science of Sociology. Chicago: The University of Chicago Press.

Park, R. E., Burgess, E. W., \& McKenzie, R. D. (2019). The City. Suggestions for Investigation of Human Behavior in the Urban Environment (1. painos 1925). Chicago: The University of Chicago Press.

Puurunen, P. (2019). Jane Addamsin sosiaalityön käsityksen rakentuminen. Kuopio: Itä-Suomen yliopisto.

Rafter, N. H. (2006). Criminal Anthropology. Its Reception in the United States and the Nature of its Appeal. Teoksessa P. Becker \& R. F. Wetzell (toim.), Criminals and Their Scientists. The History of Criminology in International Perspective (s. 159-182). New York: Cambridge University Press.

Roos, J. P. (2021). Viimeinen oikea professori - Heikki Waris. Tieteessä Tapahtuu, 39(1), 59-60. Noudettu osoitteesta https://journal.fi/tt/article/view/102673

Salerno, R. A. (2007). Sociology Noir. Jefferson, NC: McFarland \& Company Inc.

Sampson, R. J. \& Groves, W. B. (1989). Community structure and crime: Testing social disorganization theory. American Journal of Sociology, 94(4), 774-802. https://doi.org/10.1086/229068

Shaw, C. R. \& McKay, H. D. (1972). Juvenile Delinquency and Urban Areas. A Study of Rates of Delinquency in Relation to Differential Characteristics of Local Communities (1. painos 1942, uusittu painos 1969). Chicago: The University of Chicago Press. 
Shoemaker, D. J. (2010). Theories of Delinquency: An Examination of Explanations of Delinquent Behavior (6. painos). Oxford: Oxford University Press.

Short, J. F. Jr (1972). Introduction to the Revised Edition. Teoksessa C. R. Shaw \& H. D. McKay (toim.), Juvenile Delinquency and Urban Areas. A Study of Rates of Delinquency in Relation to Differential Characteristics of Local Communities (uusittu painos). Chicago: The University of Chicago Press.

Silver, E., Mulvey, E.P., \& Swanson, J.W. (2002). Neighborhood Structural Characteristics and Mental Disorder: Faris and Dunham Revisited. Social Science \& Medicine, 55(8), 1457-1470. https://doi.org/10.1016/S02779536(01)00266-0

Snodgrass, J. (1976). Clifford R. Shaw and Henry D. McKay: Chicago Criminologists. The British Journal of Criminology, 16(1), 1-19.

Springer, D. W. \& Roberts, A. R. (2006). Social Work in Juvenile and Criminal Justice Settings (3. painos). Springfield, III: Charles C Thomas.

Sutherland, E.H. (1945). Social Pathology. American Journal of Sociology, 50(6), 429-435. https://doi.org/10.1086/219682

Sutherland, E.H. (1947). Principles of Criminology (4. painos). Chicago: J.B. Lippincott Company.

Teele, J. E. (2002). Introduction. Teoksessa J. E. Teele (toim.), E. Franklin Frazier and Black Bourgeoisie (s. 1-16). Columbia, Mo: University of Missouri Press, Thomas, W. I. \& Znaniecki, F. (1984). The Polish Peasant in Europe and America (alkup. painokset 1918-1920). Toimittanut ja lyhentänyt E. Zaretsky. Chicago: University of Illinois Press.

Tonry, M. (2013). Evidence, Ideology, and Politics in the Making of American Criminal Justice Policy. Crime and Justice, 42(1), Crime and Justice in America 1975-2025, 1-18.

https://doi.org/10.1086/671382

Waris, H. ym. (1952). Siirtoväen sopeutuminen: tutkimus Suomen karjalaisen siirtoväen sosiaalisesta sopeutumisesta. Helsinki: Otava.

Wilkerson, I. (2020). The Warmth of Other Suns: The Epic Story of America's Great Migration (1. painos 2010). London: Penguin.

Williams, J. E. \& MacLean, V. M. (2015). Settlement Sociology in the Progressive Years. Faith, Science, and Reform. Boston: Brill.

Wilson, W. J. (1987). The Truly Disadvantaged: The Inner City, the Underclass, and Public Policy. Chicago: The University of Chicago Press.

Zaretsky, E. (1984). Editor's Introduction. Teoksessa W. I. Thomas \& F. Znaniecki (toim.), The Polish Peasant in Europe and America (s. 1-53). Chicago: University of Illinois Press. 


\section{ENGLISH SUMMARY}

\section{Vilma Niskanen and Petteri Pietikäinen: Crime and the theory of social disorganization in}

the studies of the Chicago School of Sociology between 1918 and 1948.

This article examines the origin and development of the concept and theory of social disorganization from the methodological perspective of intellectual history. Based on the study of publications of the main representatives of the Chicago School of Sociology between the years 1918 and 1948, the article analyses the ways in which social disorganization was first discussed by William I. Thomas, Robert E. Park and other Chicago sociologists, and how the concept and theory was later used in Shaw's and McKay's influential criminological study Juvenile Delinquency and Urban Areas (1942). At the outset, the notion of social disorganization was central to the Chicago sociologists' conceptualization of social change and social control that they observed first-hand in the streets of the rapidly growing City of Chicago. The authors argue that theory was widely used in American social science, including criminology, between the 1920s and 1950s, because it had strong explanatory force in the study of social problems in urban areas undergoing changes and re-organization. After becoming marginalized as a theory in the 1960s, a criminological interest in social disorganization increased through the 1980s, and at present it is used not only in criminology but also in area studies, urban sociology and psychiatry.

Keywords: social disorganisation - Chicago school of sociology - history of sociology and criminology - urban sociology 